Politik Ekonomik Kuram 2019, Cilt 3(2), 289-337

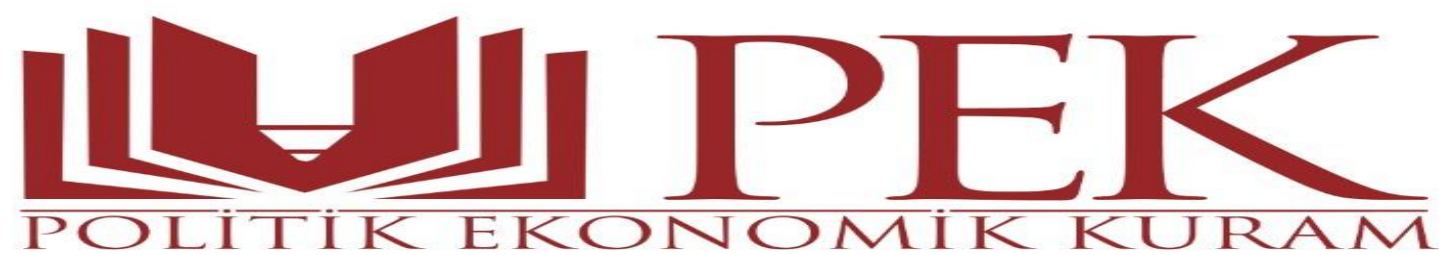

\title{
Kapitalizm, Devlet ve Köylü: Gaziantep Köylerinde Ampirik Bir Çalışma
}

Bilgen Taşdoğan ${ }^{1}$

Zeynep Ağdemir²

\section{Makale Bilgileri}

Makale Geçmişi:

Makalenin Yüklendiği Tarih: 11.11.2019

Makalenin Kabul Edildiği Tarih: 12.12.2019

Anahtar Kelimeler: Köylücü yaklaşım, tarihselci yaklaşım, küçük köylü ve devlet.

1 Dr. Öğr. Üyesi, Aksaray Üniversitesi, İktisadi İdari Bilimler Fakültesi, Maliye Bölümü, bilgentasdogan@aksaray.edu.tr.

2 Dr. Öğr. Üyesi, Kırşehir Ahi Evran Üniversitesi, İktisadi İdari Bilimler Fakültesi, Maliye Bölümü, zeynepagdemir@ahievran.edu.tr. 
Taşdoğan, B ve Ağdemir, Z.. (2019), "Kapitalizm, Devlet ve Köylü: Gaziantep Köylerinde Ampirik Bir Çalışma”, Politik Ekonomik Kuram, Cilt 3(2)

\title{
Özet
}

$\mathrm{Bu}$ çalışmanın amacı, kapitalizm ve köylülük çerçevesinde yapılan temel kuramsal tartışmalar bağlamında Gaziantep'in iki köyünde yapılan anket çalışmasından elde edilen verileri inceleyerek kapitalizm- köylülük ve devlet ilişkisine dair bazı tespitler geliştirmeye çalışmaktır. Çalışma bu amaca ulaşabilmek için öncelikle kapitalizmde köylülük tartışmalarını iki temel eksene indirgemiş, köylücü ve tarihselci anlayışın temel savlarını ortaya koymuştur. Köylücü yaklaşım küçük çiftçinin kapitalizm koşullarında devamlılığını sağlayacağını söylerken, tarihselci yaklaşım kapitalizm koşullarında küçük üreticinin mülksüzleşeceğini savunur. Yazı bu teorik tartışmanın ardından Gaziantep'in dağ ve oya köyünde bu iki teorik yaklaşımın tezlerine dair yorum yapmamızı sağlayan çeşitli kriterleri içeren anketleri sırasıyla değerlendirmiştir.

$\mathrm{Bu}$ bilgiler, köyün tarihçesi, kuruluşu, hane sayısı, arazi sorunları, ağalık düzeni, ürün türleri, pazar ilişkileri, makineleşme, toprak satışı, işçi ücretleri, kooperatifleşme ve altyapı hizmetleri, bölüşüm ilişkileri, gelir ve meslek bileşeni, üretim faktörlerine sahiplik, bitkisel üretim ve hayvancılığın birlikteliği, toprak büyüklüğü ile hane büyüklüğü ilişkisi, kapitalist üretim ilişkileri ve proleterleşme süreci, kapitalist bağımlılık derecesi, yaşam standartlarıdır. Çalışma sonuç bölümünde köylücü ve tarihselci yaklaşımının tezleri ile anket sonuçlarını değerlendirmiştir.

\section{Capitalism, the State and the Peasant: An Empirical Study in Gaziantep Villages}

\begin{abstract}
The aim of this study is to examine the data obtained from the surveys conducted in the two villages of Gaziantep in the context of the basic theoretical debates within the framework of capitalism and peasantry and to try to develop some determinations about the relationship between capitalism and peasantry and the state. In order to achieve this aim, the study firstly reduced the arguments of peasantry in capitalism to two main axes and put forward the basic arguments of the theory of peasant economy appoach and the historical approach. While the theory of peasant economy approach says that the small farmer will maintain its continuity under the conditions of capitalism, the historical approach argues that under the conditions of capitalism the small producer will be expropriated. Following this theoretical discussion, the article evaluated the questionnaires in Gaziantep's villages, which contain various criteria that enable us to comment on the theses of these two theoretical approaches. This informations are the history of the village, the establishment, the number of households, land problems, land order, product types, market relations, mechanization, land sales, labor wages, cooperatives and infrastructure services, distribution relations, income and occupational component, ownership of production factors, crop production and the association of animal husbandry, the relationship between land size and household size, the relations of capitalist production and the process of proletarianization, the degree of capitalist dependence, and the standards of living. In the conclusion part of the study, the theses of the theory of peasant economy and the historical approach and the survey results were evaluated.
\end{abstract}

Keywords: The theory of peasant economy approach, the historical approach, small peasant and state. 
Taşdoğan, B ve Ağdemir, Z.. (2019), "Kapitalizm, Devlet ve Köylü: Gaziantep Köylerinde Ampirik Bir Çalışma”, Politik Ekonomik Kuram, Cilt 3(2)

\section{Giriş}

Toplumsal olguların algılanma biçimi, bu olguları anlamaya çalışırken kullanılan metodolojinin temel kabullerine göre farklı biçimler alır. Bu yöntemsel farklılıklar her alanda yapılan çeşitli ana tartışmaların ayrılık noktalarının nedenlerini oluşturur. Ancak teorilerin açıklayıcılık gücü, ortaya attıkları soyutlama düzeyinin gerçekliği anlam gücüyle ölçülmektedir. Bu bağlamda, bu çalışmanın amacı küçük üreticiliğin kapitalizm koşullarında ne tür farklılaşmalar yaşadığı, devletin müdahalelerinin bu süreci nasıl etkilediğidir. $\mathrm{Bu}$ amaç çerçevesinde, bu çalışma Gaziantep ilinde bulunan Aceroba ve Sakçagözü köylerinde küçük üreticiler ile yürütülen 2016 yılında yapılan derinlemesine mülakat ve ankete dayalı veri toplama teknikleri kullanılarak temel sorunsalına cevap bulmaya çalışacaktır. Çalışmanın yöntemine dair detaylı veriler kapitalizm ve köylülük alanında yapılan temel literatürü kısaca incelendikten sonra ele alınmıştır. Bu çerçevede çalışma öncelikle, kapitalizm ve köylülük ilişkisine dair temel teorik tartışmaları özetlemiş, ardından pratiğe dair genel çerçevesini betimlemeye çalışmıştır.

Tarımda kapitalizm tartışmalarında temel farklılık, toplumsal olguları anlarken kullanılan temel ile ilgili görünmektedir. Köylülüğün kapitalizm içerisinde sürekliliğini vurgulayan yaklaşım olan köylücü yaklaşım toplumsal olguları değişmeyi dışlayan bir yöntemsel çerçevede ele almaktadır. Tarihselci yaklaşım için ise toplumu oluşturan sınıflar içinde sürekli değişim gerçekleşir, olgular süreç içerisinde anlamlandırılırlar. Bu çerçevede küçük üretici kapitalist koşullara bağlı olarak farklılaşacaklardır. Çalışma kapitalizm ve köylülük tartışmasındaki teorik anlatının Gaziantep'in iki köyünde ortaya çıkan sonuçlar ile birlikte değerlendirerek soyut ile somutun sınamasını yapmaya çalışacaktır. Kuşkusuz bu tür bir sınama somuta dair verilerin kısıtlı olmasından dolayı önemli sınırlara sahiptir, ancak sınırlı olsa da bazı sonuçlara ulaşabilmeyi mümkün kılabilecektir

Anket hazırlanırken tarihselci ve köylücü yaklaşımın tezlerini bu iki köyde yorumlayabilmeyi ve belki de bu iki tezin sorularına ek olacak bazı veriler elde etmeyi hedefleyen soru seti hazırlanmıştır. Anket kapsamında tüccar, muhtar ve köylülerle yapılan yüz yüze yapılan görüşmelerde köyün tarihçesi, kuruluşu, hane sayısı, arazi sorunları, ağalık düzeni, ürün türleri, pazar ilişkileri, makineleşme, göç, toprak satışı, işçi ücretleri, kooperatifleşme ve altyap1 hizmetleri, bölüşüm ilişkileri, gelir ve meslek bileşeni, üretim faktörlerine sahiplik, bitkisel üretim ve hayvancılığın birlikteliği, toprak büyüklüğü ile hane büyüklüğü ilişkisi, kapitalist üretim ilişkileri ve proleterleşme süreci, kapitalist bağımlılık derecesi, yaşam standartları ve 
Taşdoğan, B ve Ağdemir, Z.. (2019), "Kapitalizm, Devlet ve Köylü: Gaziantep Köylerinde Ampirik Bir Çalışma”, Politik Ekonomik Kuram, Cilt 3(2)

yoksulluk ilişkisi sorularına cevap aranmıştır. Sonuç olarak ise anket verileri, köylücü ve tarihselci yaklaşımın ortaya koyduğu savlar çerçevesinde değerlendirilmeye çalışılmıştır.

\section{Tarım ve Köylülük Tartışmaları}

Tarımda kapitalist üretim ilişkilerine dair literatür tartışmalarında farklı sınıflandırılmalar olsa da köylülüğün kapitalist ilişkiler içerisindeki yerini anlamaya çalış1lırken temel olarak iki tür taraflaşmanın olduğundan bahsedebiliriz: köy(lü)cü, tarihselci yaklaşım.

Önemli temsilcilerini Chayanov'un oluşturduğu köylücü yaklaşım 20. yüzyılın başında geliştirilmiş ve Rus Nardonik yaklaşımı bu tartışmalardan oldukça beslenmiştir. Bu yaklaşım köylünün kapitalist üretim ilişkileri içindeki sürekliliğini vurgulamaktayken, tarihselci yaklaşım köylünün proleterleşme sürecine vurgu yapar.

Chayanov (1966) köylülüğü incelerken, mikro birim üzerinden hareket ederek 'aile çiftliği ${ }^{3}$ ' kavramını kullanmaktadır. Chayanov'un aile çiftliği kâr amaçlı girişim değil, aile üyelerinin emeği ile işlenen tarımsal alanları ifade etmektedir. Chayanov üretim faktörlerine ücret, rant, kira ve faiz şeklinde herhangi bir ödemede bulunmayan, tipik bir çiftçi aile için emek-tüketim dengesini bulmaya çalışmaktadır. Bunun için ailenin gelirinden yıllık üretimin masraflarını ve sonraki yılın yeniden üretim girdilerini düşmekte, kalanını ise tüketmesi gerektiğini belirtmektedir. Burada emek, toprak ve sermaye birbirinden ayrılmamakta, üretim ve tüketim bir arada bulunmakta ve meta ticareti ikincil olarak bir hayat tarzı şeklinde devam etmektedir (Chayanov, 1966). Chayanov'un betimlediği “bu tarz kapitalist olmayan ve köylü emekçilerin aile birimleri üzerine temellenen bir tarzdır" (Amin, 1997: 101).

\footnotetext{
${ }^{3}$ Chayanov'un aile çiftliği kavramı BM tarafindan 2014 yılında 'aile çiftçliği'ne uyarlanmış ve ailelerin doğdukları toprakları terk etmeyerek hane emeğini kullanan birimler olarak yaşadıkları toprakları kalkındırmaları yönünde tavsiyeler sunulmuştur. BM bu süreci azgelişmiş ülkeler için demokratikleşme, hane bütünlüğü ve kültürün korunması üzerinden miras yolu ile bölünmüş arazilere bağlayarak aile ortaklığı kavramını destekleyici olarak sunmuştur (Gıda ve Tarım Bakanlığı, 2014). Türkiye'de de aynı yıl tarımsal/aile ortaklığı ya da aileden birinin toprağı işlemesi, ya da kimse yapmak istemiyorsa; kardeşlerin sadece 65 dönüm ve üzeri toprakları 3. kişiye toprakları satması hukuki dayanağa kavuşturulmuştur. Sürecin finansmanı için ise pozitif ayrımcılık olarak adlandırılan 'Aile Çiftçiliği Bankacılığı' türetilerek tarla büyütme kredisi ile küçük payların tek elde toplanması hedeflenmiştir (Şekerbank, 2017).
} 
Taşdoğan, B ve Ağdemir, Z.. (2019), "Kapitalizm, Devlet ve Köylü: Gaziantep Köylerinde Ampirik Bir Çalışma”, Politik Ekonomik Kuram, Cilt 3(2)

Bununla birlikte, bu hanelerin ellerindeki tek ölçü toplam çalışmalarının sonunda ürettikleri net üretim miktarı olduğu için parasal değerlendirme yapılamamaktadır. Örneğin, çalışma günü başına düşen buğday bulunamamaktadır. Çalışma gününün uzunluğu değerlendirmeye konu olmakta ve çoğu ailenin yeniden üretimini sağlayabilmek için ya daha uzun ve/veya daha yoğun çalışması gerekmektedir. Chayanov kendini yeniden üretebilmek için köylünün yaptığı bu çalışma biçimini 'kendi emeğini sömürme"' olarak tanımlamaktadır (Chayanov, 1966).

Diğer taraftan her ailenin ihtiyaçları ve çalışma koşulları arasında kuracağı denge, ailenin beslemek zorunda olduğu birey sayısı ve aile içi emek gücüne göre değişmektedir. Chayanov, bu dengeyi sürdürecek “üretimin örgütlenmesi”ni, “demografik farklar” olarak yorumlamıştır. Bu aynı süreci "sınıflar arası farklar" olarak yorumlayan Lenin ve Kautsky'den de ayrışma anlamını taşımaktadır. Bu nedenle de Chayanov'un aile çiftliği kapitalist çiftlik / çiftçi değildir. Çünkü aile çiftçisi kapitalist çiftçinin aksine giderleri gelirlerini aştığı noktada çalışma koşullarını ağırlaştırıp ürünleri düşük fiyatlardan satarak ve hiç artık elde etmeyerek yıldan yıla çiftçiliğine devam etmektedir. Dolayısıyla aile çiftçisi, kapitalist işletmeler karşısında uzun süre direnebilmektedir (Chayanov, 1966).

Kautsky (1988) bir olgu olarak köylülüğün ayırt edici özellikleri olduğunu savunarak köylücü grupta yer alan Shanin gibi sermayenin tarımı egemenliği altına alması ve eski biçimlerinden dönüştürme yolları üzerinde durmuştur. Bu kapsamda kapitalizm, tarımda sanayiden farklı gelişerek öncelik tarımsal yapıları parçalamaktadır. Büyük ölçekli tarımsal yapılar makine kullanımı üzerinden küçük ölçeklilere baskı uygulayarak tarıma girmektedir (Kautsky, 1988: 99). Makine kullanımı, bilimsel araştırmalar gibi konularda avantajlı olan büyük tarımsal

\footnotetext{
${ }^{4}$ KMÜ; geçimlik üretim ve yeniden üretimin metalaşmış kapitalist üretim ilişskileri içinde gerçekleştirebildiği yapılar olması yanında hane emeğinin metalaşmaması ve geçimlik üretimin devam etmesi tartışmalar yaratmaktadır (Ecevit, 1994: 94). KMÜ özünde metalaşmamış aile emeğine dayanması ve sermaye birikimi yaratmaması yanında Türkiye gibi azgelişmiş ülkelerde genellikle göç eden erkeklerin boşalan emeklerinin yerini hane içi kadın ve çocuk emeklerinin ikame etmesi KMÜ’nin varlığını devam ettirebilmesi, farklılaşması ve ortadan kalkma süreç ve eğilimlerinin açıklanmasında belirleyici olmaktadır (Ecevit, 1994: 104). Diğer taraftan bu ikame biçimi bir anlamda kadın ve çocuk emeğinin kendi kendini sömürmesi biçimine dönüşmüştür.

Aydın (1980)'e göre küçük köylülük; tarımsal üretim, balıkçılık, hayvancılık, kauçuk toplayıcıları vb.uğraşan, kendi toprağına sahip olup geçinmek için toprağını kiraya veren ya da topraksız olup kiracı ya da ortakçı olanları ve temel olarak varlığını idame ettirmeyi amaçlayanları kapsamaktadır.
} 
Taşdoğan, B ve Ağdemir, Z.. (2019), "Kapitalizm, Devlet ve Köylü: Gaziantep Köylerinde Ampirik Bir Çalışma”, Politik Ekonomik Kuram, Cilt 3(2)

yapılar verimlilik üzerine temellenmektedir. Yaygın tarımın yapıldığı bu yapılar ulaşım, sulama sistemi gibi altyapının uygun olduğu, ticaret ve kredi mekanizmalarının geliştiği yerleri üretim alanları olarak seçmektedir. Kol emeğinin yoğun kullanıldığg küçük çiftçilik ${ }^{5}$ bağcılık, seracılık gibi yoğun tarımla uğraşmaktadır. Büyük çiftçiler karşısında ücretli çalışandan farklı olarak çalışma saatini ve yoğunluğunu uzatabilme ve daha tutumlu olabilme özelliklerine sahiptir (Kautsky, 1988: 99 -110). Kautsky küçük çiftçilerin bu durumunu 'aç kalma sanatı' olarak adlandırmakta ve ekonomik üstünlüğün bir yolu görmektedir. Fakat teknolojinin (makinelerin) tarıma sokulması ile avantajlar büyük çiftçiler yararına olmaktadır (Kautsky, 1988: 114 -118). Kautsky’nin “aç kalma sanatı sahibi” betimlemesini, Amin (1997), kültürel eğilimleri içermesi, yani kapitalizmin tek bir tipi ve tek bir sınıf yapısının olmaması çerçevesinde olumlar. Kautsky, küçük işletmelerin büyük işletmeler karşısında yaşamlarını sürdürdüklerini hatta bazı ürünlerde avantaj sağladıklarını, hatta 19. yüzyıl Avrupa'sında küçük tarım işletmelerinin kaybolmak yerine sayısal olarak arttığını Almanya örneği üzerinden anlatmaktadır (Aydın, 1986: 135136). ${ }^{6}$ Banaji ve Bernstein da Kautsky'den etkilenerek Almanya'daki sanayi devrimi sonrasi kapitalizm karşısında küçük üreticileri analiz etmişlerdir. Analizlerinde tarımda temel üretim aracı olan toprağın savaş, işgal gibi istisnai artırımlarının dışında, sınırlı ellerde biriktiği için proleterleşen ücretli emekten öte, üreticilerin boyunduruk altına alındığı mekanizmaların önemine değinmişlerdir (Aydın, 2016: 44). Banaji, Bernstein'ın aynı zamanda küçük köylüğün gizli proleter olduklarını yani; sermayenin, hane üretiminin koşullarını kontrol ettiğini ve artıktan (üretimden) haneye kalan kısmın aslında örtülü ücret olduğunu iddia etmektedirler. Kapitalizm ile hane arasındaki bu karşılıklı ilişki nedeniyle, sermaye daha fazla artık elde etmeye çalışırken hane de kendini yeniden üretmeye çalışmaktadır (Aydın, 1980: 12).

\footnotetext{
5 "Köylülük”, "küçük köylülük” gibi kavramlar Chayanov - Shanin çizgisine aitken "küçük meta üretimi” marksist bir kavramsallaştırmadır. Köylülük artık 2000'li yıllarda iç farklılaşmasının her bir öğesi ile kapitalist piyasa ilişkilerinin belirlenimine tabi olduğu için küçük köylülük gibi bir incelemede, bu üreticiliğin görüngüsel varlı̆̆ında heterojen özellikleri, gerçek varlığında ise homojen özellikleri daha baskın durumdadır (Özuğurlu, 2011: 80). Boratav (2010), küçük üreticiliği üretim araçlarının tümüne (toprak dahil) sahip olan, üretimi ücretli emek kullanmadan aile/hane içi emek ile sürdüren ve üretimi temel olarak tüketim amaçlı yapan sınıf olarak tanımlamaktadır (Boratav, 2010: 221; Boratav, 2004: 51-54).

${ }^{6}$ Aydın (1986) tarım sorununu Marksist anlamda incelemek için sorunu tarımdaki işletmelerin gelecekteki kaderi olarak ortaya koymak yerine, tarımsal üretim tarzının temelinde yatan varyasyonların incelenmesi gerektiğini, sermayenin tarımı hakimiyeti altına alıp almadığı, onu değiştirip değiştirmediği, eski üretim ve mülkiyet biçimlerini işlemez duruma getirip getirmediğini ve yeni biçimlere yol açıp açmadığını ve tüm bunları nasıl yaptığı gibi soruların cevabının bulunması gerektiğini belirtmektedir (Aydın, 1986: 136).
} 
Taşdoğan, B ve Ağdemir, Z.. (2019), “Kapitalizm, Devlet ve Köylü: Gaziantep Köylerinde Ampirik Bir Çalışma”, Politik Ekonomik Kuram, Cilt 3(2)

Köycü yaklaşım ${ }^{7}$ da öne çıkan Wolf (1999), köylülük sorunu, toplumdaki büyük tarım kökenli nüfusun değişim ve modernleşme karşısındaki varoluş mücadelesini incelemektedir. Wolf’a göre küçük köylü yoğun tarımla uğraşmakta ve temel olarak kendi ihtiyaçlarını üretmektedir. Kurumsallaşmış yoksulluğun olduğu bu kitlelerde hane üretici ve tüketici birimidir (Aydın, 1980: 4). Piyasa için üretim yapan diğer bir küçük köylü tipi daha bulunmaktadır ki, ürünlerin \%50-75'i düzenli olarak piyasaya sunulmakta ve dolayısıyla ilk gruba göre daha yoğun sermayeye gereksinim duymaktadırlar (Aydın, 1980: 5).

Yine köylücü yaklaşım içerisinde yer alan Shanin (1971), küçük köylülüğü geleneksel, ancak kendi öz geçimini sağlayan hane emeği üzerine dayanan, dünya nüfusunun ve dünya yoksullarının çoğunluğunu oluşturan en yaygın üretim birimi olarak tanımlamaktadır. Shanin küçük köylülüğün en temel özelliğini emeğinin karşılığını alamama olarak tanımlamakta ve tarım işçileri, topraksız köylüler, kır esnafları, köy tüccarları ve gecekonducular aynı grupta değerlendirmektedir (Aydın, 1980: 7).

Tarihselci yaklaşım, tarımı kapitalizmin tarihsel belirleniminde bir üretim faaliyeti olarak ele alarak tarımsal yapıların dönüşümüne odaklanmaktadır (Özuğurlu, 2011: 69). Bu yaklaşımda kapitalist üretim tarzının devamı için küçük ölçekli meta üreticisinin ${ }^{8}$ varlığı zorunlu

\footnotetext{
${ }^{7}$ Cumhuriyetin kurulması ile birlikte 1945 'e kadar tarım üzerinden örgütlenmeye giden idareciler köycü ideolojiyi kendilerine zemin almışlardır. Bu kapsamda köylerin sömürüsü üzerinde yükselen, hem sanayileşmeyi hem de işçi sınıfının gelişmesini engelleyen işçi isyanı, işsizlik, grev, ötekileşme vb. unsurları barındıran şehirleşmeye ve proleterleşmeye karşı olunmuştur. Hakim olan köycü ideoloji sanayileşme yaşanmadan sanayi kurulmasını ve bu sanayinin de devlet tarafından şehirlerin dişında bir köycü sanayi olması gerektiği, böylelikle köylünün topraksızlaşma sonucu şehirlere göçüp proleterleşmesinin önleneceğini savunmuşlardır (Karaömerlioğlu, 1998).

${ }^{8}$ Küçük ölçekli meta üretimi de kapitalizmin kendi gibi pek çok görüngü halini alabilmekle birlikte küçük meta üretiminin varlığı üzerinden kapitalizmin ekonomi politiği içinde teorileştirilmektedir. Kapitalizmin ideal tipinin işlevsel hale getirilmesi piyasa mantığı olan değer yasası üzerinden kavramsallaştırmalıdır. Bu açıdan metalaştırma emeğin hareketliliğinin, toprak ve kredinin bir fonksiyonu olmaktadır. Dolayısıyla metalaşma piyasa fiyatlarından satın alınan malların zaman içindeki oranı ile ölçülebilir. Aynı zamanda bu üç değişkenin aynılığı ücret, kira ve faiz oranlarının zaman ve mekansal değişimine göre ölçülebilir. Örneğin ücret beceri, kira verimlilik ve lokasyon, faiz oranı ise risk vb. faktörlere göre değişebilmektedir. Dolaysıyla değer yasası ve piyasa-fiyat ilişkileri kendi içinde karmaşık bir görüngüdür. Bu ilişkinin ölçülebilir düzeye indirgenmesi sadece daha çok ya da daha az kuramsal veya daha çok ya da daha az (türev) olarak niteleyebilmemize yardım eder ki bu da kapitalizmin ekonomi politiğine ilişkin pek çok meseleyi kendiliğinden çözememektedir (Bernstein, 1986: 23).
} 
Taşdoğan, B ve Ağdemir, Z.. (2019), "Kapitalizm, Devlet ve Köylü: Gaziantep Köylerinde Ampirik Bir Çalışma”, Politik Ekonomik Kuram, Cilt 3(2)

görülmemektedir. Köylücü yaklaşım köylüyü kültürel ve sosyolojik bir 'olgu' olarak savunmaktadır (Önal, 2017: 732). Tarihselci yaklaşımda ise sermaye ve emek tarafindan gerçekleştirilen tarımsal üretim Marx ve Engels'in tanımladığı "kapitalist toplumun toplumsal eğilimlerinden biri” olan orta sınıfların mülksüzleşmesi üzerine kurgulanmaktadır (Önal, 2017: 732).

Tarihselci yaklaşımın köylülüğe bakış açısının netleştirmek için Marx'ın (2006) köylülüğe dair tespitlerin bakmak faydalı olacaktır.

“Kendi kendini yöneten köylünün özgür mülkiyetinin küçük ölçekli faaliyet için ... toprağa tasarrufun bir önkoşulu olduğu ... çiftçinin daima kendi geçim araçlarını bağımsız olarak ailesi ile birlikte ... üretmesi gerektiği ... açıktır... Toprak sahipliği de bu üretim tarzının tam gelişimi için gereklidir. Kişisel bağımsızlı̆̆ın gelişmesinin temeli buradadır.... Onun yıkıllısıını getiren nedenler ... şunlardır:... Geniş ölçekli sanayinin gelişmesi ... toprak parçalarının yönetiminin ikinci bir ekini oluşturan ve sığır yetiştirmesinde olanak sağlayan tek şey olan ortak topraklarını büyük toprak sahipleri tarafindan gaspedilmesi ve plantasyon sistemini ya da geniş ölçekli tarımın rekabeti. Bir yandan tarımsal fiyatlarda bir düşüşe yol açan öte yandan daha büyük harcamalar ve daha yaygın maddi üretim koşulları gerektiren tarımdaki iyileştirmeler de bu durumda katklda bulunur. 18. yüzyllın ilk yarısında İngiltere'de olduğu gibi.

Küçük ölçekli toprak mülkiyeti, niteliği gereği, emeğin toplumsal üretken güçlerinin gelişmesini, emeğin toplumsal biçimlerini, sermayenin toplumsal yoğunlaşmasını geniş ölçekli sı̆̆ır

Bu görüngü bazen bir köylü grubunun toplumsal varoluşunu genel meta üretiminin parçası olmasına bağlarken bazen de ulusal ekonomiler, sektörler, dallar, meta üretim biçimleri, emeğin işbölümü ve piyasa ve fiyat hareketleri üzerinden eşitsiz gelişmeyi ifade eder. Dolayısıyla ileri veya geri kalmış, kapitalist-kapitalizm öncesi şeklindeki sınıflandırmalar kapitalist ekonomi biçimlerinin ayrıştırılması anlamına gelmektedir. Bu da bizi küçük meta üretiminin genel meta üretiminin olduğu bir durumda sömürülen bir sınıf olmaktan öte metalaşmanın paylaştırıldığı kategorilerden biri olduğu sonucuna götürmektedir. Üretimin 'az gelişmişliği' sınıflandırması kolektif çalışma yaratamaz, emeği karmaşı işbölümlerine sokamaz, emek sürecini toplumsallaştıramaz, yaygın bir işbirliği yaratamaz. Göreli ve mutlak artık değerlerin KMÜ'nin çeşitli biçimlerine uygulanabildiği durumlarda göreli artık değer hane içi emek kısıtından dolayı sınırlamalarla karşılaşmakta ve 'üretici güçler' ve 'emeğin üretkenliği' gerekliliği KMÜ’nde kapitalist üretim biçimine göre daha az gelişmektedir. Ölçek ekonomileri ve her işçinin kapitalistleşmesi varsayımları altında küçük üreticiler yeni tip üretim ilişkilerinde görünürler. Kapitalizm var olduğu sürece KMÜ'de var olmuştur. Dolayısıyla buradaki tartışma tamamlanamamış ya da başarılamamış bir kapitalist dönüşüm mü olduğu ya da kapitalizmin çevre/ geri ilişkilerinin özgün özelliği mi olduğudur (Bernstein, 1986:25). Bu ilişkinin sosyalizm ile bağdaştırılabilmesi için de bölüşümün belirleyicilerinin piyasa mantığından arındırılması gerekmektedir (Boratav, 2010: 270). 
Taşdoğan, B ve Ağdemir, Z.. (2019), "Kapitalizm, Devlet ve Köylü: Gaziantep Köylerinde Ampirik Bir Çalışma”, Politik Ekonomik Kuram, Cilt 3(2)

yetişstiriciliğini ve bilimin ilerici uygulamasını dışlar. Tefecilik ve vergi istemi her yerde ona güç kaybettirir. Toprağın fiyatına yapılan sermaye harcaması, bu sermayeyi tarımdan çeker. Üretim araçlarının sinırsız parçalanması ve bizzat üreticilerin tecridi. Insan enerjisinin korkunç israfi. Üretim koşullarının giderek artan kötüleşmesi ve üretim araçları fiyatlarında artış- toprak parçaları mülkiyetinin kaçınılmaz bir yasası (Marx, 2006: 708-709).

Marx, burada küçük toprak sahibini yok oluşa iten sebepleri geniş ölçekli sanayi, toprakların tarımsal olarak zayıflaması, tarımsal rekabet, fiyat artışları, tefecilik, toprağın fiyatına yapılan sermaye harcaması, parçalı toprak yapısı, toprak gaspı ve vergiler olarak saymaktadır. Engels (1990) Fransa'da ve Almanya'da Köylü Sorunu eserinde küçük köylüyü, feodal üretim tarzından farkını, ve kapitalizm karşısındaki durumunu;

“Küçük köylüden, burada, onun ailesi ile birlikte kural olarak işleyebileceğinden daha büyük, ve ailenin beslenmesi için zorunlu olandan da daha küçük olmayan bir toprak parçasının sahibini ya da kiracısını - özellikle sahibini-anllyoruz"” (Engels, 1850 [1990]: 139).” şeklinde anlatır.

Küçük köylü "kendi atası olan” serften Fransız Devrimi ile feodal bağlılıktan kurtularak, küçük toprak mülkiyeti ve emeği dışındaki üretim araçlarından büyük ölçüde yoksun olarak ve takas sistemini terk ederek ayrılmakta ve proleterleşmektedir (Engels, 1850 [1990]: 139-140).”

“Vergiler, kötü hasatlar, paylaşmalar, birbirleri arkasına tefecinin ocağına düşürürler, borçlanma her biri için gitgide daha genel ve gitgide daha büyük bir şey olur; klsacası bizim küçük köylümüz, aşılmış bir üretim biçiminin her tür kalıntısı gibi, çaresiz bir biçimde yıkıma mahkûmdur. Gelecekteki bir proleterdir"(Engels, 1850 [1990]: 140).

Bizim için ayrıca önemli olan husus vergilerin burada küçük köylüğü proleterleştiren bir etkiye sahip olması, devletin mali araçlarının toplumsal yapıları dönüştürebileceğidir.

Lenin ise küçük köylünün geleceğini konusunda Marx ve Engels ile örtüşen görüşlere sahiptir. Tarımda Kapitalizm (1996) ve Tarım Meseleleri (1997) eserlerinde tarımda kapitalizmin işleyişini göstererek küçük köylülügün gittikçe yok olduğunu ${ }^{9}$ ortaya koymaktadır. Her iki eserde de Lenin küçük köylülüğün varlığına ve büyüdüğüne ilişkin tezlerin yanlış olduğunu, bunun küçük köylülüğü toprak alanı üzerinden anlayan analizlerden ileri geldiğini belirtmektedir.

\footnotetext{
9 Köylülüğün yok oluşu tartışmasını Bernstein (2003) sermaye ve emek arasındaki sınıf ilişkileri üzerine yoğunlaştırmakta ve tarımı emeğin uluslar arası emperyalizm tarafindan bölünüşüne yerleştirmektedir.
} 
Taşdoğan, B ve Ağdemir, Z.. (2019), "Kapitalizm, Devlet ve Köylü: Gaziantep Köylerinde Ampirik Bir Çalışma”, Politik Ekonomik Kuram, Cilt 3(2)

\begin{abstract}
"Kapitalist tarımın temel gelişme çizgisi, küçük çiftliklerin, alan bakımından hala küçük kaldıkları halde üretimin çapı, hayvan çiftliğinin gelişmesi, kullanılan gübre miktarı, makine kullanılma derecesi vb. bakımlarında büyük çiftlik haline gelmeleridir.

Gerçekten kapitalizmin temel ve başlica eğilimi hem endüstri hem de tarım alanlarında küçük üretimin büyük çapta üretim tarafindan ortadan kaldırlmasıdır. Ancak, bu süreç, sadece doğrudan doğruya mülksüzleştirme anlamında alınmamalıdır. Bu ortadan kaldırma süreci yıllarca sürebilecek olan, küçük çiftçilerin tarımda çalışma şartlarının ylkılması ve kötüleşmesi sürecini de içine alır. Bu kötüleşme, küçük çiftçinin fazla çalışmast veya beslenme yetersizliği, artan bir borç yükü; hayvan yemlerinin ve genel olarak hayvanların içinde bulunduğu şartların kötüleşmesi, toprağı gübreleme ve işleme metotlarında gerileme, teknik ilerlemenin durması vb. şeklinde kendini gösterir" (Lenin, 1996: 99-101).
\end{abstract}

Lenin Tarım Meseleleri eserinde Amerika Birleşik Devletleri’ni inceleyerek kapitalist tarımın dağılmakta olduğu, küçük emekçi çiftliklerin yaygınlaştı̆̆ı iddialarının gerçeğe aykırı olduğunu ortaya koymaktadır. Lenin Amerika Birleşik Devletleri’ni ekonomik durumuna göre “endüstriyel Kuzey, eskiden köleci Güney ve sömürgeleştirilmiş Batı” olarak üçe ayırmakta ve batıdaki çiftlik artışının sebebini boş toprakların tasarruf hakkının dağıtılması olarak belirtmektedir. Yani, kapitalizmin toprağa farklı biçimlerde sızdığını ve kapitalizmin topraktaki mülkiyet biçimlerini kendine bağladığını örneklendirmektedir (Lenin, 1996: 83-86).

“Amerika Birleşik Devletleri'nde ... ĕger çiftlik başına değil dekar başına yapılan harcamalara bakarsak tarımın çapının tarımın entansifliğine göre küçüldüğ̈̈ görülmektedir”. Burada vurgulanmak istenen toprakta kullanılan makineleşme, gübreleme vb. harcamaların farklı olduğu durumların tarımın kapitalist olduğu ülkelerde geçerli olan entansif gelişme olduğudur. Yani sadece toprak alanına bakarak küçük çiftçilik hakkında yorum yapmak kapitalizminde tarım açısından temel eğilimleri göstermemektedir (Lenin, 1996: 95-99).

Lenin, büyük toprakların toplam topraklar içindeki payını, büyük toprak sahiplerinin toplam değer ve toplam harcamalarının ülkedeki toplam harcama ve toplam değer içindeki payına göre çiftliklerin kapitalistlik derecesini yorumlamaktadır (Lenin,1996: 103-105). Lenin, Rusya'da Kapitalizmin Gelişimi (1975) incelemesinde ise gelişmiş kapitalist ülkelerde küçük köylülüğün geleceğine ilişkin çıkarımlarda bulunmaktadır:

“Bu köylü kategorisine ait bağımsız tarımsal emek, muhtemelen, yalnızca en iyi yıllarda, ve özellikle elverişli koşullar mevcut olduğu zaman geçimlerini karşılarlar, bunun için de durumları son derece tehlikelidir. Orta köylü, çoğu kez emek-hizmeti vb. ile ödenmek üzere borçlanma yoluna başvurmadan, gene, kısmen, işgücünün satılması demek olan, fazladan bir “yardımcı” iş aramadan vb. iki yakasını bir araya getiremez. Her kötü hasat, orta köylü yı̆̆ınlarını proletarya saflarına firlatır. Toplumsal ilişkilerinde, bu grup, ĕ̌ilim duyduğu, ama ancak küçük bir mutlu azınlı̆̆ın dahil olmayı başardiğı üst 
Taşdoğan, B ve Ağdemir, Z.. (2019), "Kapitalizm, Devlet ve Köylü: Gaziantep Köylerinde Ampirik Bir Çalışma”, Politik Ekonomik Kuram, Cilt 3(2)

grupla, tüm toplumsal evrim hareketiyle itildiği alt grup arasında sallanıp durur. Böylece, özel olarak, kapitalist ekonomiye has olan bir süreç yer alır, ortadaki üyeler silinip gider, uçtakiler pekişir. Bu, "köylülükten çılkma” sürecidir. (Lenin, 1975: 186) Köylülüğün farklllaşmasl, kapitalizm için bir iç pazar yaratır. Alt grupta, pazarın oluşumu, tüketim maddelerinden dolayı gerçekleşir (kişisel tüketim pazarı). Kır proletaryasl, orta köylülüğe oranla, daha az tüketir, üstelik de, en kötü kalitede yiyecek tüketir (ekmek yerine patates vb.), ama daha çok satın alır. Bir köylü burjuvazinin oluşması ve gelişmesi ise, iki biçimde pazar yaratır: Birinci ve esas olarak, üretim araçları için (üretken tüketim pazarl), çünkü hali-vakti yerinde köylülük gerek "zor durumdaki” toprak beylerinden, gerekse ylkım halindeki köylülerden "topladığı" üretim araçların sermayeye dönüş̧ürme çabasındadır. Ikkincisi, daha zengin köylülerin gereksinmelerinin artmasindan dolayı, burada da, kişisel tüketim için bir pazar yaratıllı” (Lenin, 1975: 181-182).

Kısaca, tarihselci yaklaşım, köylülüğü sınıf ve sınıf mücadeleleri üzerinden analiz etmektedir (Önal, 2017: 732). Bu tartışmalarda ortaya çıkan kavram ve görüş ayrılıkları 1960 ve 1970'li yıllarda 3. Dünya ülkelerinin sanayileşme problemleri ile tekrar gündeme gelmiştir (Aydın, 1986: 126). Modernleşme Okulu'nun, ekonomik kalkınmanın Batı Avrupa ülkelerinin (İngiltere) yaşadığı süreçle gerçekleşeceği yargısı, sanayileşememiş ülkelerde kalkınma yanılsamaları yaratmıştır (Frank, 1966: 28). Bu yanılgı kapitalizmin homojen bir tarihsel sürece sahip olduğu düşüncesinden kaynaklanmaktadır Ancak tarihin zaman ve mekana göre parçalı ve çelişkili bir sürecine bakıldığında, sanayileşmiş ülkelerin çoğu durumda gelir ve kültür yönünden ikili yapı sergiledikleri görülmektedir. Bu ikili yapı sermayenin yayılma sürecinden beri bir arada bulunmakta ve günümüzdeki emperyal sömürü ve kapitalist eklemlenme olgularını ortaya çıkarmaktadır (Frank, 1966: 29-30).Ülkelerin iç dinamiklerini ve tarihsel özgünlüklerini dikkate almayan modernleşme yaklaşımı, köylülüğe de ortak bir tip yaratmaktadır. $\mathrm{Bu}$ çerçevede köylülük ya aile emeğine dayanan kırsal üreticilerle eşdeğer tutulmakta ya da tüm kır üreticileri homojen "köylü” adında toplanmaktadır. Bu genel tanım, feodal ranta dayanan Orta Çağ Avrupa köylüsü ile meta rantına dayanan günümüz üçüncü dünya köylülerini eşdeğer tutmaktadır. Böylelikle, kalkınma için "modern” kapitalist sektörden "geleneksel” geçimlik tarım sektörüne bilgi, beceri ve teknoloji transfer edilmesi gerekmektedir (Aydın, 1986: 129-130). Modernleşmeci kuram üçüncü dünya köylüleri arasında ve ulusal düzeyde kendi içlerindeki farklılaşmaları dışladığı için tarımın kapitalizmin gelişmesindeki rolü ve yerini açıklamaktan uzak kalmaktadır (Aydın, 1986: 131).

Tarımda kapitalizme dair yapılan tartışmanın genel hatlarından sonra teori ile pratiğin bir sınamasını yapmak için pratiğe dair çeşitli bilgilerin verilmesi faydalı olacaktır. 
Taşdoğan, B ve Ağdemir, Z.. (2019), "Kapitalizm, Devlet ve Köylü: Gaziantep Köylerinde Ampirik Bir Çalışma”, Politik Ekonomik Kuram, Cilt 3(2)

\section{Yöntem}

Çalışmanın önceki bölümünde belirtildiği üzere köylülüğün kapitalizme eklemlenme biçimi önemli bir sorunsaldır. Türkiye'de 1960 ve 70 dönemi daha yoğun olmak üzere Mübeccel Kıray, Bahattin Akşit, Çağlar Keyder, Metin Özuğurlu, Zülküf Aydın, Mehmet Ecevit vb. sosyoloji temelli çalışmacılar monografik çalışmalarla teorik düzeyde yapılan tartışmaları desteklemişlerdir.

Tarımda kapitalist eklemlenmenin en yaygın biçimi olan pazar ilişkilerinde ağalık düzeni, tüccar- tefeci sermayesi ve pazara yakınlık ön plana çıkarılmaktadır. Bu ilişkilerde pazara yakınlık derecesini köyün arazi yapısı ve verimliliği, yetiştirilen ürünün cinsi ve arazi büyüklükleri desteklemektedir. Çünkü kapitalistleşme süreci dağ ve ova köylerinde farklı ilerlemektedir. Çalışma bu tartışmayı, teori ve pratik arasında bir ilişki kurabilmek adına ilk bölümde yer yer ele alınsa da belirginleştirmek amacıyla bu başlık altında ele almayı ve örneklem seçimine yansıtmayı tercih etmiş̧tir.

Literatürde ova köyleri, kapitalizmin üzerinde yoğunlaştı̆̆ 1 temel tipini oluştururken dağ köyleri, piyasa ilişkilerini (tüccar-tefeci sermayesi, finansallaşma, Çok uluslu şirketlerin sözleşmeli üreticilik üzerinden köylüleri kedi topraklarında işçileştirmesi gibi) görece daha az barındırmaktadır. Çünkü bu tipte küçük toprak mülkiyeti ve yetersiz sulama ve kurak araziler, eğim gibi olumsuz arazi koşulları ve görece pazara uzaklık üretim riski ve verim ilişkisinde riski artırmaktadır. Dolayısıyla günümüzde ova köyleri kapitalizmin tarımda yönelmek istemediği temel alanları oluşturmaktadır. Bahsi geçen ilişkiler Güneydoğu Anadolu Bölgesinde oldukça sık görülmektedir.

Bu kapsamda Güneydoğu Anadolu Bölgesinde yer alan Gaziantep İli, hem adı geçen ilişkileri içermesi hem de önce çevre illerden, 2013 sonrası ise Suriye'den gelen mevsimlik iş̧̧ilerin yoğun bulunduğu bölgelerden biri olması açısından ön plana çıkmaktadır. Başka bir deyişle Gaziantep'te dağ ve ova köyleri bulunmaktadır. Bu iki tipin de bir arada görüldüğü Nurdağı İlçesinin tercih edilme sebebi bu biçimde açıklanabilir. İki köy aynı ilçede ve birbirine yakın mesafede bulunmaktadır. Yani köylerin pazara (şehir bey ilçe merkezine uzaklıkları) uzaklıkları çok farklı olmamakla birlikte ova köyünde piyasa ilişkileri görülürken, dağ köyünde görülmemektedir. Dağ köyünde ise farklı bir piyasa ilişkisi (toprağı satma) görülmüştür 
Taşdoğan, B ve Ağdemir, Z.. (2019), "Kapitalizm, Devlet ve Köylü: Gaziantep Köylerinde Ampirik Bir Çalışma”, Politik Ekonomik Kuram, Cilt 3(2)

$\mathrm{Bu}$ ilişskileri ortaya koyabilmek amaçlı ilk bölümde açıklanan bilgileri destekleyen, yorumlamaya ve örneklendirmeye yönelik niceliksel araştırma yöntemlerinden betimsel araştırma yöntemi tercih edilmiştir. Bu yöntemde var olan problemin mevcut durumu kendi koşullarında görülmek istenmiştir. Duruma açıklamaya ilişkin sorulara cevap bulabilmek amaçlı anket çalışmasına, gözlem ve görüşme yöntemine yönelinmiştir. Bu yöntem gözlem, görüşme, konu ile ilgili veri toplama ve verilerin analiz edilmesi, konuyu destekleyici diğer açıklayıcı bilgilerin doğal ortamlarından örneklerle aktarılması vb. çizgiyi takip etmektedir.

Elde edilen nicel verilerin betimlenmesinde aritmetik ortalama istatistiklerinden faydalanılmış ve sonuçlar tablolar üzerinden sunulmuştur. Anket çalışması kapsamında bahsi geçen ilişkileri yansıttığı düşünülen Gaziantep İli, Nurdağı İlçesine bağlı iki köy (6360 sayılı kanun ile mahalle kapsamına alınmıştır) evren olarak ele alınmıştır. Köylerle ilgili detaylı bilgiler sonraki kısımda ele alınmakta olup, temsil gücünün yüksek olması açısından örneklem olarak köy hane sayısının \%10'una derinlemesine mülakat ve ankete dayalı veri toplama teknikleri kullanılmıştır. Örneklem kümesinin özelliklerine bakıldığında ise köylerin dağılımları ile orantılı olarak topraksız, küçük, orta ve büyük köylü ${ }^{10}$ kategorilerinden kişiler seçilmiştir. Anketin ve görüşmeler hem yazılı hem de ses kaydı olarak alınmıştır. Soruların güvenilirliğini ve tutarlılığını sağlamak amaçlı birbirini doğrulayan çapraz sorulara yer verilmiştir ${ }^{11}$.

\section{Tarım ve Küçük Köylülü̆̆̈̈n Analizi: Aceroba ve Sakçagözü Köyleri}

İncelenen köylerden Aceroba Köyü, dağ köyüdür. Köyün temel altyapı ihtiyaçları 6360 sayılı kanun sonrası tamamlanmıştır. Köyün kente ve en yakın ilçe merkezine uzaklığı 25 'er km'dir. 1990 yılında 361 kişinin yaşadığı köyde mevcut durumda 261 kişi yaşamaktadır. Onaylı yerleşim planı olan köyde yabancılara toprak satışı bulunmaktadır. Köyden tamamen göç eden aileler vardır. Köyün başlıca gelir kaynakları tarım ve hayvancılıktır. Köyde ihtiyaçlar için salma usulü ile para toplanmıştır. Köylülerin alışverişte tercih sırası önce ilçe merkezi

\footnotetext{
${ }^{10}$ Bu kavram coğrafya, ekilen ürün ve zamana göre değişmektedir. Örneğin, Cumhuriyetin ilk yıllarında 100 dekar ve altı asgari geçimlik toprak, 101-200 dekar arası orta üreticilik, 201 ve üzeri ise büyük toprak sahipliğini yansitırken (Köymen, 1999: 2,4); 1950'lerde, 2-50 hektar arası küçük, 51-100 hektar arası orta, 101 - 500 aras1 büyük ve 501 üzeri kapitalist tarım işletmesi olarak sınıflandırılırmıştır (Köylü, 1947: 6,7). Günümüzde ise 1-50 hektar küçük, 5-100 orta, 101-500 hektar büyük ve 500 üzeri kapitalist tarım işletmesi sayılmakta olup (İslamoğlu, 2008: 66,69), işletmelerin \% 53'ü 0-50 hektar, 67,5'si ise 0-100 dekar arası büyüklükte yoğunlaşmaktadır (TUIKK, 2019)

${ }^{11}$ Sorular Ek’te yer almaktadır.
} 
Taşdoğan, B ve Ağdemir, Z.. (2019), "Kapitalizm, Devlet ve Köylü: Gaziantep Köylerinde Ampirik Bir Çalışma”, Politik Ekonomik Kuram, Cilt 3(2)

sonrasında il merkezidir. Köyün kuruluş tarihi 1810 yılı olmakla birlikte, Kahramanmaraş’ın, Pazarcık İlçesinde yaşayan Çavdar Ağa ve etrafı, bu köyü yayla olarak kullanmakta iken zamanla Pazarcık’ta sivrisineklerin çokluğu gerekçesiyle köy kalıcı yerleşim yeri haline gelmiştir. Günümüzde köyde toplam 30 hane bulunmaktadır. Günümüzde ağalık ilişkilerinin bulunmadığı köyde araziler ile ilgili sorunlar bulunmaktadır. Dağ köyü olan bu yerleşim yerinde düz arazi oldukça sınırlı olup, köylülerin toplam arazisi 200 dekar miktarındadır. Köyde makinalı tarıma son beş yıl içerisinde geçilmiştir. Köydeki genç nüfus eğitim ve istihdam olanakları için kente göç vermektedir. Toprak satışının yoğunlaştığı köyde, alternatif geçim kaynağı mangal kömürcülüğü olmuştur. Köyde meyve, sebze, fistık ve üzüm ağırlıklı olarak üretilmektedir. Ürünler hallere ve tüccarlara verilmektedir. Köyde tüccar ve kooperatif bulunmamaktadır. Köyde bankadan kredi kullanımı giderek artmakta olup, krediler Ziraat Bankası ve İş Bankası tarafından sağlanmıştır

Sakçagözü K̈̈yünde 1970 yılında 5573 dönüm araziyi devlet köylüye bedelsiz olarak verilmiştir. Kalan araziler ise toprak ağasından para ile satın alınarak elde edilmiştir. Köyün toplam arazi büyüklügü 24.732 dönümdür. Köyde toplam 1375 hane vardır. Köyün toplam arazileri ile ilgili tapu sorunu bulunmaktadır. Hazine arazileri köylüler tarafından tarım alanı olarak kullanılmaktadır. Topraklar miras yolu ile bölünmüş durumdadır. Köyde yetiştirilen ürünlere bakıldığında; Nurdağı, Pazarcık bölgesinde pirinç (çeltik) ekimi yapılmakta iken yaşanan sıtma salgını ve ıslah çalışmaları sonucu pamuk ve buğday ekimine geçilmiştir. Günümüzde de birincil ürün olarak pamuk, yer yer misır ve ikincil ürün olarak buğday ekilmektedir. Köyde makineleşme 1955 'lerde başlamıştır. Köyün pazarla ilişkisi tüccar aracılığı ile olmuştu. Özellikle sulama alanında kooperatifleşmenin gelişmesine ihtiyaç duyulduğu, kooperatiflerin 2006 sonrası şirket gibi davranmaya başladığı belirtilmektedir. Köy dışı toprak satışı yaygın olup, topraklar ağırlıklı olarak dışardan gelenlere satılmaktadır.

\subsection{Anket Sonuçlart}

Anketin yapıldığı iki köy birbirinden farklı özellikler göstermekte ve farklı sonuçlar elde edilmektedir. Tablo-1'de yer alan köy özet bilgilerinden de anlaşılacağı üzere Sakçagözü’nde köy hane sayısının \%9’u, görece oldukça küçük dağ köyü olan Aceroba için ise toplam hanelerin \%65'ine anket çalışması yapılmıştır. Sakçagözü’nde sözleşmeli üreticilik ve pamuk 
Taşdoğan, B ve Ağdemir, Z.. (2019), "Kapitalizm, Devlet ve Köylü: Gaziantep Köylerinde Ampirik Bir Çalışma”, Politik Ekonomik Kuram, Cilt 3(2)

buğday üretimi yapılırken, düz arazisi oldukça sınırlı olan Aceroba' da sebze, meyve, fıstık gibi ürünler yetiştirilmektedir.

\section{Tablo 1: Köy Özet Bilgileri}

\begin{tabular}{|l|l|l|}
\hline Köy Adı & Sakçagözü & Aceroba \\
\hline Toplam hane sayısı & 1375 & 40 \\
\hline Anketin hane sayıs1 & 121 & 26 \\
\hline Anket hane oranı (\%) & $\% 9$ & $\% 65$ \\
\hline Sözleşmeli üreticilik (\%)* & $\% 12$ & - \\
\hline Buğday/ Pamuk (\%) & $\% 85$ & - \\
\hline Bahçecilik (\%)** & $\% 3$ & $\% 100$ \\
\hline
\end{tabular}

* Sözleşmeli üretim ile mısır ve patates ekilmektedir. Sözleşmeli ekim yapanların \%71'i mısır, \%29'u patates ekmektedir. ** Bahçecilik ile sebze, meyve, biber, fıstık, ceviz kastedilmektedir.

Patates ekimi için; Pepsi, Lays firması ile sözleşme yapılmaktadır. Şirket tohumdan hasat aşamasına kadar denetim ve girdi tedariki sağlamaktadır. Şirket tohum, ilaç, gübre gibi girdilerin ya kendinden alınmasını ya da şirketin belirlediği markalardan alınmasını şart koşmaktadır. Nihai aşamada şirket alım yaparken de patatesin büyüklük standartlarına bakmaktadır. Örneğin çok büyük ya da küçük patatesler alınmamakta, dolayısıyla çiftçinin büyük zararları söz konusu olmaktadır. Sözleşmeli üreticilik yapanlara nedeni sorulduğunda, alım- satım garantisinin olması, girdi tedarikinde faiz uygulamaması ve devletten yüksek fiyat vermesi sıralanmıştır. Diğer taraftan ise sözleşmeli üreticiliği patates maliyetinin çok yüksek olması, şirketin kota koyması, ve diğer şartlar nedeniyle zararlı bulup vazgeçenler de bulunmaktadır. Örneğin şirket üreticiye dönüm başı 3 ton üzerinden sözleşme imzalatmaktadır. Yani 20 dönüme tarlaya sahip bir üretici için 60 ton sınırı oluşmaktadır. 60 tonun üzerinde üretemeyen üretici, hasat zamanı 60 tondan az ürün aldığında şirketten parasını eksik almaktadır. 60 tonun üstünde ürün aldığında ise şirket alım yapmamaktadır. Ayrıca şirketin toprağı verim düzeyi, arazinin düzlüğü, sulama durumu gibi şartlarını karşılayanlar sözleşmeli üretici, yani kendi topraklarında işçi olabilmektedirler. 
Taşdoğan, B ve Ağdemir, Z.. (2019), "Kapitalizm, Devlet ve Köylü: Gaziantep Köylerinde Ampirik Bir Çalışma”, Politik Ekonomik Kuram, Cilt 3(2)

Mısır da ise başka bir Çok Uluslu Şirket olan Du Pont'a ait Pioneer Şirketi ${ }^{12}$ ile sözleşme yapılmaktadır. Yine patates üretimi gibi toprak analizi uygunsa tonaj başına sözleşme yapılmakta arazi tapusu istenmektedir. Ayrıca köyde PANKOBİRLİK'in şeker pancarı ekimi için toprak kiralamaya başladığı belirtilmektedir.

Tablo 2: Toprak Büyüklüğüne (Dekar) Göre Hayvancılık Oranı *

\begin{tabular}{|l|l|l|l|l|l|l|l|}
\hline & $\begin{array}{l}\text { Hayvancılık } \\
\text { oranı }\end{array}$ & $0-10$ & $11-20$ & $21-50$ & $51-100$ & $101-200$ & $201-300$ \\
\hline Sakçagözü & $\% 50$ & $\% 2,5$ & $\% 4$ & $\% 40$ & $\% 42$ & $\% 7$ & $\% 4$ \\
\hline Aceroba & $\% 100$ & $\% 81$ & $\% 15$ & $\% 4$ & & & \\
\hline
\end{tabular}

*Burada toprak büyüklüğü ile hayvancılık ile uğraşma arasındaki ilişki anlaşılmaya çalış1lmıştır.

Tablo 2'de toprak büyüklükleri ve hayvancılık ile ilgili bilgiler bulunmaktadır. Sakçagözü'nde köylülerin yarısı bitkisel üretim yanında hayvancılık yapmaktadır. Hayvancılık yapanların \%57'si 50 dönüm ve altı toprağa sahip bulunmaktadır. Hayvancılık yapanların \% 87'si gelir için hayvan yetiştirmekte, \% 25'i ücret elde etmekte, \% 25'i toprağını kiraya vermekte ve \% 60’1 kendi topraklarını ekmektedirler. Yine hayvancılık yapanlar ağırlıklı olarak keçi yetiştirmektedir. Bölgede keçi sütü ağırlıklı olarak MADO şirketine ya da keçi yoğurdu ve peyniri olarak kente ve diğer köylere satılmaktadır. Yine canlı hayvan da köylü tarafından bireysel olarak satılmaktadır. Köylülerin \% 43'nün traktörü bulunmakta ve traktörü olanların da \% 17'sinin 50 dönüm ve altı toprağı bulunmaktadır.

Aceroba'ya bakıldığında, köylülerin \% 80'den fazlası 0-10 dönüm toprağa sahip olmaktadır. $\mathrm{Bu}$ dağ köyünde hiç toprağı olmadığ 1 halde köyde yaşayan hane bulunmamaktadır. Oysa Sakçagözü'nde toprağı olmadığı halde köyde yaşayıp ücretli işçilik ya da ortakçılık yapan topraksız köylüler bulunmaktadır. Aceroba'daki köylülerin \% 12’sinin traktörü bulunmaktadır. Bunlar da 10 dönüm ve üzeri toprağı olan köylülerden oluşmaktadır. Köylülerin tamamı hayvancılık yapmaktadır, köylüler ek gelir elde edebilmek için besicilik yapmaktadırlar.

\footnotetext{
12 Şirket Türkiye'deki çalışmalarına 1985 'te başlamakla birlikte merkez ofisini 1986 'da İstanbul'da açmış ve 1987'de Adana'da tohum işleme fabrikasını kurmuştur. Trakya, Adapazarı, Bursa, aydın, Adana, Karadeniz ve GAP bölgesinde faaliyet gösteren tekel; mısır, buğday, ayçiçeği, kanola hibrit tohumlarında da Türkiye'de tekel konumunda (http://www.pioneer.com/web/site/turkey/about_us/our_history/Pioneer_Turkey_history).
} 
Taşdoğan, B ve Ağdemir, Z.. (2019), "Kapitalizm, Devlet ve Köylü: Gaziantep Köylerinde Ampirik Bir Çalışma”, Politik Ekonomik Kuram, Cilt 3(2)

Tablo 3'te köylülerin gelir türlerine göre ayrıştırılmaya çalışılmıştır. Bu çerçevede Aceroba'nın hem kent merkezine yakınlığg, hem de üretim araçlarının görece elverişsizliği nedeniyle anket kapsamında değerlendirilen hanelerin neredeyse tamamının ücret geliri elde ettiği görülmektedir.

Tablo 3: Köylünün Elde Ettiği Gelir Tipi

\begin{tabular}{|l|l|l|l|l|l|l|}
\hline$(\%)$ & Ticari kar & Toprak kira & Tarım gelir & Ücret & $\ddot{U}$.geçici & Ü. kalıcı \\
\hline Sakçagözü & 8 & 29 & 100 & 30 & 36 & 47 \\
\hline Aceroba & - & - & 100 & 96 & 36 & 64 \\
\hline
\end{tabular}

Sakçagözü'nde ise ücret elde edenlerin \%17'si işini geçici veya kalıcı diye tanımlayamamıştır. Geçici işçilerin tamamına yakını ücretli tarım işçiliği yapmaktadır. Ücret geliri elde edenlerin yaptıkları işlerden bazıları hamallık, şoförlük, bakkal, garsonluk ve vasıfsız fabrika işçiliğidir. Ticari kâr elde edenlerin \%30’u 100 dönüm ve üzeri toprağa sahiptir. \% 30'u 50 dönüm alt1, \%40'ının ise 50-100 dönüm arası toprağı bulunmaktadır. Ücret elde edenlerden \%69'u 50 dönüm ve altında toprağa sahip olan köylülerdir. Ücret elde edenlerin \% 39'u topraklarını işlemek yerine kiraya (ortakçı, icar) vermekte ve kira geliri elde etmektedir. Toprağını kiraya verenlerin \% 51'i 50 dönüm ve altında toprağı olanlardır.

Refah göstergelerinin yer aldığı Tablo 4, toprak büyüklüğü ve hane büyüklüğü ilişkisini ortaya çıkarmaya çalışmaktadır.

Tablo 4. Refah Göstergeleri (\%)

\begin{tabular}{|l|l|l|}
\hline & Sakçagözü & Aceroba \\
\hline Toprak kiralar & $\% 13$ & 0 \\
\hline Toprak kiraya verir & $\% 37$ & 0 \\
\hline Satılan toprak & $\% 31$ & $\% 39$ \\
\hline Boş bırakılan toprak & $\% 7$ & $\% 31$ \\
\hline Satılan makine & $\% 12$ & Köyde makine yok \\
\hline Kendi çalışır & $\% 77$ & $\% 100$ \\
\hline
\end{tabular}


Taşdoğan, B ve Ağdemir, Z.. (2019), "Kapitalizm, Devlet ve Köylü: Gaziantep Köylerinde Ampirik Bir Çalışma”, Politik Ekonomik Kuram, Cilt 3(2)

\begin{tabular}{|l|l|l|}
\hline Ücretli işçi çalıştırır & $\% 42$ & 0 \\
\hline $\begin{array}{l}\text { Haneden diğer tarım } \\
\text { işlerinde çalışan }\end{array}$ & $\% 11$ & $\% 69$ \\
\hline K/Ç* çalışır & $\% 30$ & $\% 100$ \\
\hline $\begin{array}{l}\text { K/Ç olmadan üretim } \\
\text { devam etmez }\end{array}$ & $\% 84$ & $\% 100$ \\
\hline
\end{tabular}

*K/ Ç, Kadın Çocuk.

Sakçagözü̈nde toprak kiralayanların \%25'i 50 dönüm ve altı toprağı olan köylüdür. Toprak kiralayan küçük köylüler geleneksel ürünler olan pamuk, buğday yerine sebze ekimi yapmakta, yani hane emeğinin yoğun kullanıldığı entansif tarım yapmaktadırlar. Bu ekim karşılığı ürün desteği almamaktadır. Toprağını kiraya verenlerin \% 51'i 50 dönüm ve altı toprağı olanlardır. Bunların \% 49'u ücretli işçi, \% 44'ü ise hayvancılık yapmaktadır. Toprağını satan köylülerin \% 29'u ücretli işçilerden, bu grubun da \% 82'si 50 dönüm ve altı toprağa sahip olanlardan oluşmaktadır. Burada belirtilmesi gereken nokta, toprak satışlarının önemli bir kısmının 2006 sonrası gerçekleşmiş olması ve toprak satanların (1 köylü hariç) 0-50 dönüm arası toprak satmış olmasıdır. Dolayısıyla \% 82'lik grup toprak satışı sonrası 50 dönüm ve altı topră̆ı olan köylü grubuna girmiştir. Bu ise tarihselci yaklaşımı haklı çıkararak orta grup köylünün küçük gruba yakınsadığını doğrulamaktadır. Diğer taraftan toprak satanların \% 59'u hayvancılıkla uğraşmakta ve çoğunluk ihtiyaçtan dolayı satış yaptığını belirtmektedir. Azınlık bir grup ise hayvan almak için toprağını sattığını belirtmektedir. Bu da hayvancılıkta da köylülüğün reel bir gerileme içinde olduğunu göstermektedir.

Boş bırakılan arazilerde tüm gruplardaki köylüler yer almaktadır. Makine satışlarında yine tüm gruplar yer almaktadir.

Tarım işlerinde çalışanları 0-200 dönüm arası toprağı olan köylüler oluşturmaktadır. 201-300 dönüm topră̆ı olanlar tarım işlerinde çalışmadıklarını belirtmektedir. Toprakta bilfiil çalışmayanların \% 46'sı ücretli işçilerdir. Toprakta çalışmayan büyük çiftçilerden (201- 300 dönüm toprağı olanlar) \%60’1 2 aya kadar işçi çalıştıran 55 yaş üstü çiftçilerden oluşmaktadır. \%40’lık kesim ise ortalama 6 ay işçi çalıştıran 30 yaş ortalamasındaki köylülerden oluşmaktadır. Diğer tarım işlerinde çalışanlardan \% 62'si 50 dönüm ve altı toprağı bulunanlar, \%15'i ise 200 dönüm ve üstü toprağı olan köylülerdir. 
Taşdoğan, B ve Ağdemir, Z.. (2019), "Kapitalizm, Devlet ve Köylü: Gaziantep Köylerinde Ampirik Bir Çalışma”, Politik Ekonomik Kuram, Cilt 3(2)

Kadın ve/veya çocukların çalıştığı grubun \% 50’si 50 dönüm ve altı toprağı olan köylülerdir. Bunların \% 22'si ise aynı zamanda hayvancılıkla uğraşmaktadır. Diğer bir önemli gösterge olan kadın ve çocukların çalışmadan üretimin devam edebileceğini düşünenlerin \%47'si 50 dönüm ve altı toprağa sahip olanlardır.

Toprak dışındaki önemli üretim aracı ve aynı zamanda refah göstergesi olan traktör sahipliği köylülerin \%43’ünü kapsamaktadır. Traktörü olmayanlar kiralamakta, yardımlaşmakta ya da 4 kardeşin ortak traktör alması gibi maliyeti paylaşmaktadır. Bu bölgede toprak killi, sert olduğu için beygiri yüksek traktör kullanılmaktadır. Toprak 50 dönümden fazla ise 55 beygirden büyük traktörler kullanılmaktadır.

Aceroba'da, köy şehir merkezine yakın olduğu için arazilerinin değerli olduğu belirtilmektedir. Araziler ağırlıklı olarak şehirde yaşayanlarca alınıp bağ evi olarak kullanılmaktadır. Dolayısıyla köylü borçlarını kapatmak için zaten az olan topraklarını daha küçük parseller halinde kolayca satıp ihtiyaçlarını karşılamaktadır. Köyün pazarla ilişkisi temel ihtiyaçları karşılamak dışında sınırlı olmakta ve köyde bakkal, tüccar gibi aracılar ve pazarla ilişki kurulabilecek bir alan bulunmamaktadır.

\section{Tablo 5: Bağımlılık ilişkileri}

\begin{tabular}{|l|l|l|}
\hline$(\%)$ & Sakçagözü & Aceroba \\
\hline Birikim & $\% 5$ & 0 \\
\hline Haneden göç & $\% 8$ & $\% 65$ \\
\hline Sağlık güvencesi & $\% 31$ & $\% 27$ \\
\hline Emekli maaşı & $\% 12$ & $\% 42$ \\
\hline Sendika destek/katılım & $\% 97$ & $\% 92$ \\
\hline Ürün desteği & $\% 96$ & 0 \\
\hline Yardım alan & $\% 10$ & 0 \\
\hline Girdi alma biçimi & $\% 4$ peşin & $\% 100$ veresiye \\
\hline Girdi tasarrufu & $\% 3$ tasarruf yapar & $\% 12$ \\
\hline Ürünü satış & $\% 26$ aynı & $\% 50$ kendi, $\% 50$ hal \\
\hline Banka borcunu öder & $\% 20$ & $\% 58$ \\
\hline
\end{tabular}


Taşdoğan, B ve Ağdemir, Z.. (2019), "Kapitalizm, Devlet ve Köylü: Gaziantep Köylerinde Ampirik Bir Çalışma”, Politik Ekonomik Kuram, Cilt 3(2)

\begin{tabular}{|l|l|l|}
\hline Kredi kartı var & $\% 39$ & $\% 62$ \\
\hline Borçsuz yıl var & $\% 12$ & $\% 77$ \\
\hline
\end{tabular}

Köylülerin bağımsız üretim yapma ve geçinebilme derecesini yansıtan Tablo 5'e bakıldığında Sakçagözü’nde köylülerin birikim yapabilen \% 5'lik kısmı hayvancılık, ticari kâr ve ücret ile desteklenen hanelerdir. Sadece bitkisel üretimle uğraşıp birikim yapabilenler ise toplamın \% 0,8 'ine denk gelmektedir.

Katılımcılara sendika ile ilgili sorular yöneltilmiş ve sendika köylünün örgütlenme organı olarak anlatılmıştır. Yani köylünün kooperatif benzeri bir yapıda bir araya gelerek girdileri toplu alması, ürünü toplu satması, makinelerin ortak alınarak kullanımı gibi köylü yararına ortak hareket edilmesi şeklinde tanımlanmıştır. Bu yönlendirme sonucu köylülerin \%97'si “bir köylü sendikası kurulsa üyesi olur musunuz?” sorununa olumlu yanıt vermiştir.

Köylülerin piyasaya eklemlenme ilişkilerini yansıtan sorularda \% 26'sı girdileri aldığı ve ürünü sattığı yerin aynı tüccar olduğunu belirtmektedir. Üretim için gerekli girdiler tüccardan veresiye alınmakta ve ürün satışında tüccar borcu keserek ödemede bulunmaktadır.

Ürün desteği almayanların \%80’i hayvancılıkla uğraşmaktadır. Yine \%80’i ücretli işçilik yapmaktadır, \%60’1 ise hayvancılık ve ücretli işçilik yapmaktadır.

Geçinmek için devlet yardımı alanların da \%42'si hayvancılıkla uğraşmakta, bunların \%17'si ise ücret elde etmektedir. Dolayısıyla kayıt dışılığın kabaca bu düzeyde olduğunu söyleyebiliriz.

Banka üzerinden borçluluk ilişkilerinin sorulduğu kısımda borcunu ödeyebilenlerin \%46'sının hayvancılıkla uğraştığı, yine borcunu ödeyebilen ücretli işçilerin oranının da \% 46 düzeyinde olduğu görülmektedir. Hem hayvancılık ile uğraşıp hem ücretli işçi olanlar \% 25' düzeyindedir. Dolayısıyla sadece bitkisel üretim yapıp banka borcunu ödeyebilenlerin oranı \% 7'dir.

Banka borcu olmadığını söyleyenlerin \%43’ü yine hayvancılıkla geçinmektedir. Buradan da yine bitkisel üretim yapanların \%3'nün bankalara borçlanmadığı sonucu ortaya çıkmaktadır.

Kredi kartı kullananların \% 45'i borcunu düzenli ödediğini belirtmekte ve borcunu düzenli ödeyebilenlerin \% 48'i ilave olarak hayvancılık geliri elde etmektedir. Bu grubun \% 33'ü ise ilave ücretli işçilik yapmaktadır. Kredi kartı borcunu düzenli ödeyenlerden \% 33'u yalnız bitkisel üretim yapmaktadır. Kredi kartı borcunu düzenli ödeyen ve sadece bitkisel üretim yapanlardan banka kredi borcunu da düzenli ödeyebilenler \% 33 düzeyindedir. Kredi kartı 
Taşdoğan, B ve Ağdemir, Z.. (2019), "Kapitalizm, Devlet ve Köylü: Gaziantep Köylerinde Ampirik Bir Çalışma”, Politik Ekonomik Kuram, Cilt 3(2)

borcunu düzenli ödeyenlerden banka borcunu da düzenli ödeyebilenler \% 38 oranındadır. Borçsuz yıl geçirdim diyenlerin \%50'si sadece bitkisel üretim ile uğraşmaktadır ve bunların da $\%$ 43'ü 200 dönüm ve üzeri toprağ 1 olan köylülerdir.

Burada belirtilmesi gereken bir nokta köylünün finans sermayeye bağımlılı̆ııın yaratılma şeklidir. Köylülerle yapılan görüşmelere göre, köylülerin çiftçilere özel girdi alımı için kullanılan kartları tüccar borçları için kullandığı böylelikle de tüccardan tekrar borçlandığı bu nedenle 2001 sonrasında toprak satışının hızlandığı görülmektedir.

Özetle tarımsal üretim tek bir alanla sınırlandığında, yani bitkisel üretim ile hayvancıllğıın organik bağı koparıldığında, üretici köylünün geçimlik düzeyde üretim yapabilen oranı ortalama $\% 5$ düzeyinde olmaktadır. Bu da tarımın bitki- hayvan-balıkçılık alanında bir bütün iken anlamlı olacağını göstermektedir.

Aceroba Köyü’nden edinilen bilgilerde ise; sağlık güvencesi olanların \% 86's1 emekli olduğu, sağlık güvencesi olmayanların ise yeşil kartlı olduğu sonucuna ulaşılmıştır. Köylüler arazi yapısı ve küçüklüğü nedeniyle bulunduğu bölge için destekleme kapsamına alınan pamuk, buğday ve mısır ekememekte; meyve, sebze, ceviz ve fistık üretimine yönelmektedir. Dağ köyü olması nedeniyle iklim ve arazilerdeki su durumu da bu ürünlerin yetiştirilmesine müsaittir. Fakat bu ürünlerde destekleme kapsamında bulunmamaktadır. Köye son yıllarda su getirilmesine rağmen ekilen ürünlerde ve yöntemlerde değişikliğe gidilmemiş, sadece verim artışları görülmüştür. Köylü gübreyi beslediği hayvanlardan elde etmekte, ilaç ve sertifikalı tohum kullanmamaktadır. Fide ve ağaçları aşılama yöntemi ile kendileri üretmektedirler. Dolayısıyla girdi maliyetlerindeki yükselişlerden etkilenmemektedirler. Yetiştirdikleri ürünlerin de fiyatları piyasada yüksek olduğu için tarımsal gelir elde edebilmektedirler. Fakat araziler çok küçük olduğu için geçimlik üretim devam etmektedir. Köylülerin girdi olarak aldığ 1 tek ürün hayvan yemidir.

Köylünün \% 35'i banka borcunu ödeyemediğini, \% 8'de borcu olmadığını belirtmiştir. Kredi kartı olanların \% 31'i borcunu düzgün ödeyememektedir. Borçsuz yılın olmadığını söyleyenlerin oranındaki yükseklik değerlendirilirken, haneye ücret ve hayvansal gelir girdiği göz önünde bulundurulmalıdır.

\subsubsection{Yoksullaşma ve Kapitalizme Eklemlenme Sakçagözü Köyü}


Taşdoğan, B ve Ağdemir, Z.. (2019), "Kapitalizm, Devlet ve Köylü: Gaziantep Köylerinde Ampirik Bir Çalışma”, Politik Ekonomik Kuram, Cilt 3(2)

Sakçagözü'nde yaşanan tarımsal yoksullaşma köylüler tarafından çeşitli nedenlere bağlanmıştır. Buna göre, 2000 öncesi 20 dönüm toprağı olan köylünün mevsimlik işçi çalıştırmazken gelinen noktada her işi ücretli işçilerin yaptığ 1 ve zarar ettikleri belirtilmektedir. Pamuk fiyatı ve mazot fiyatı arasındaki farkın çiftçi aleyhine açılması, mısır ekmek için gerekli makine fiyatlarındaki yükselme, sulama ve elektriğin artan maliyetleri önemli sorunlar olarak dile getirilmiştir. Pamuk üretiminde işçi maliyetleri önemli bir gider kalemi olarak değerlendirilmiştir. Kısaca tarımsal üretimde girdi maliyetlerinin fiyatının, ürün fiyatına göre artması olumsuz bir gelişme olarak değerlendirilmiştir.

Diğer yandan, köylü-tefeci-tüccar arasındaki ilişkinin anlaşılması için, köyün en büyük tüccarı ile ortalama bir köylünün köyün temel ürünleri olan pamuk ve buğday için yaptıkları maliyet hesabı üzerinden bölüşüm ilişkileri incelenmiştir.

Pamuk için bölüşüm ilişkilerine bakıldığında; pamuğun fiyatının dünya piyasasına göre belirlendiğini, dünya genelinde pamuğun kıt olduğu yıl fiyat artışı tam tersi süreç de ise fiyat azalışları yaşandığını söylenmektedir. Genel bir ortalamaya vurulduğunda pamuk üreticisi kendi toprağını ekmesi durumunda ortalama \%18,5; toprak kiralaması durumunda ise \%55 oranında zarar etmektedir. Buğday üretiminde ise kaba zarar oranı \% 40 ve \%153 olmaktadır. Üstelik bu oran sonraki yılın ekimi için ayrılacak masrafları kapsamamaktadır. Bu açıdan bakıldığında ve yukarıda açıklanan oranlar göz önüne alındığında köylünün aslında tarımsal üretimi temel geçim kaynağı yapmak yerine yan gelir elde etmek için kullandığı akla gelmektedir. "Köy ayaklı proleter"13" denilen emek geliri elde eden fakat köyde yaşamaya devam eden "modern” köylü üreticiler ağırlıklı olarak yürüttükleri vasıfsız işlerinden elde ettikleri ücretlerini temel geçim unsuru yapmaktadır. Köyle olan bağlarını koparamayan ya da koparmayan bu kesim tarlalarını boş tutmakta, borçlarına karşılık ipotek ettirmekte ya da büyük toprak sahiplerine kiraya vermektedirler.

Daha detaylı incelendiğinde, 20 ve 45 dönüm toprağı olan iki çiftçinin 2016 yılı için yaptığı maliyet ve gelirlerine baktığımızda sırasıyla Tablo 6 ve Tablo 7'deki verilere ulaşılmaktadır. Köylü üretici pamuk için mazot, tohum, işçilik, gübre, ilaç ve sulamayı girdi olarak kullanmaktadır. Sulamada kullanılan su yer altı suyu olup su ücreti ${ }^{14}$ ve suyu çeken makinelerin

\footnotetext{
${ }^{13}$ Detaylı bilgi için bknz. /Özuğurlu, 2011) .

${ }^{14} 6360$ Sayılı yeni büyükşehir yasası, md. Ek fikra 28'e göre; tüzel kişiliği kaldırılarak tek mahalleye dönüştürülen beldelerde içme ve kullanma suları için alınacak ücret 31/12/2022 tarihini de kapsayacak şekilde en düşük tarifenin
} 
Taşdoğan, B ve Ağdemir, Z.. (2019), "Kapitalizm, Devlet ve Köylü: Gaziantep Köylerinde Ampirik Bir Çalışma”, Politik Ekonomik Kuram, Cilt 3(2)

kullandığı elektrik faturası gider kaydedilmektedir. Buğday üretiminde ise pamuk üretimi içi yapılan giderlere ek olarak ürünün toplanma (hasat) aşamasında kullanılan biçerdöver maliyeti bulunmaktadır. Hesaplar köylü üreticilerin kendi topraklarını ektikleri ve toprak kiraladıkları (icar) duruma göre ayrı ayrı yapılmıştır. Köylünün kendi üretim aracının sahibi olmaması durumunda üretim yapması oldukça anlamsız hale gelmektedir.

Tablo 6: Çiftçi Gider Hesabı

\begin{tabular}{|l|l|l|l|l|}
\hline & \multicolumn{3}{|l|}{ PAMUK } & \multicolumn{2}{l|}{ BUĞDAY } \\
\hline Maliyet türü & Maliyet (TL) & Maliyet (\%) & Maliyet (TL) & Maliyet (\%) \\
\hline Mazot & $2.289 \mathrm{TL}$ & $\% 8,2(6,2)$ & $377 \mathrm{TL}$ & $\% 7,5(4,18)$ \\
\hline Tohum & $600 \mathrm{TL}$ & $\% 2,1(1,6)$ & $1.120 \mathrm{TL}^{* * *}$ & $\% 22,3(12,4)$ \\
\hline İşçilik & $13.000 \mathrm{TL}^{*}$ & $\% 46,3(35)$ & $60 \mathrm{TL}$ & $\% 1,2(0,6)$ \\
\hline Gübre & $4.184 \mathrm{TL}$ & $\% 14,9(11,3)$ & $2.115 \mathrm{TL}$ & $\% 42,1(23,5)$ \\
\hline İlaç & $3.500 \mathrm{TL} * *$ & $\% 12,5(9,4)$ & $507 \mathrm{TL}^{* * * *}$ & $\% 10,1(5,6)$ \\
\hline $\begin{array}{l}\text { Sulama } \\
\text { (Elektrik) }\end{array}$ & $4.500 \mathrm{TL}$ & $\% 16(12,2)$ & $600 \mathrm{TL}$ & $\% 12(6,7)$ \\
\hline$\underline{\text { Biçerdöver }}$ & $=$ & - & & \\
\hline$\underline{\text { TOPLAM }}$ & $\underline{28.073 \mathrm{TL}^{* * *}}$ & $\% 100$ & $5.019 \mathrm{TL}$ & $\% 100$ \\
\hline
\end{tabular}

\%50'sin, aşmamalıdır. (mevzuat, 2019). Bu maddeye göre 01/01/2023 itibariyle yasa kapsamında yer alan köylülerin sulama giderlerinin $\% 50$ artacağı söylenebilmektedir. 
Taşdoğan, B ve Ağdemir, Z.. (2019), "Kapitalizm, Devlet ve Köylü: Gaziantep Köylerinde Ampirik Bir Çalışma”, Politik Ekonomik Kuram, Cilt 3(2)

\begin{tabular}{|c|c|c|c|c|}
\hline $\begin{array}{ll}\text { Dönüm } & \text { baș1 } \\
\text { maliyet } & \end{array}$ & $\underline{623,84 \mathrm{TL}}$ & & $250,95 \mathrm{TL}$ & \\
\hline$\underline{\text { İcar alınırsa }}$ & $9.000 \mathrm{TL}$ & $(24,3)$ & $4.000 \mathrm{TL}$ & $(44,4)$ \\
\hline $\begin{array}{l}\text { İcarlı Toplam } \\
\text { Maliyet }\end{array}$ & $\underline{37.073 \mathrm{TL}}$ & $(100)$ & $9.019 \mathrm{TL}$ & $(100)$ \\
\hline $\begin{array}{l}\text { Dönüm baș1 } \\
\text { maliyet }\end{array}$ & $823,84 \mathrm{TL}$ & & $450,95 \mathrm{TL}$ & \\
\hline
\end{tabular}

* ücretli işçi ortalama 20-30 gün arası çalışmaktadır.

** pamuk hasadına kadar 4 defa ilaçlama yapılmaktadır.

*** üreticiler buğday için kullanılacak tohumun sertifikalı ve önceki ürünün hasadından ayrılan normal tohum şeklinde ikili sınıflandırmaya tabi tutulduğunu belirtmektedir. Normal tohumun maliyetinin sertifikalı tohumun yarı fiyatına denk geldiğini, ancak sertifikalı tohum kullanmayan üreticilerin devlet desteklerinden de faydalanamadıklarını belirtmektedir. Dolayısıyla hesaplama sertifikalı tohum fiyatına göre yapılmıştır.

**** Sertifikalı tohum kullanarak buğday üreten üreticiler tohum (17 TL), fare (50 TL) ve ot (440 TL) olmak üzere üç farklı ilaç kullanmaktadır. Yukarıda bu üç ilacın toplam maliyetleri belirtilmiştir.

Gelir hesapları da giderlerle paralel olarak toprak mülkiyeti olma ya da kiralama durumuna göre ayrı ele alınmıştır. Burada dikkat çeken konu köylünün küçük ya da orta büyüklükte bir işletme olması durumunda kendi toprağının yanında ilave toprak kiralasa dahi üretim sürecinden zarar göreceğidir. Bir diğer dikkat çeken konu özellikle buğday üretiminde köylülerin sertifikalı tohum dışında kullandıkları girdiler için destek alamamalarıdır. Oysa köylüler toprak yanında en temel girdi olan tohuma para ödemenin ötesinde, tek sefer üretim yapılabilen bu tohumlardan ürün elde edebilmek için beraberinde satılan patentli gübre ve ilaçları da kullanmaları zorunluluklarını belirtmektedir. Yani devlet sertfikalı tohum üzerinden bu tohumun bağlı girdilerinin de kullandırılmasını üstlenmiş görünmektedir. Köylü üreticiler ise bu sürece iki şekilde tepki vermektedir. Ya destek almak için sertifikalı tohumu kullanmakta fakat kimyasal gübre ve ilaçları oldukça sınırlı düzeyde alabilmektedir. Ya da desteği reddedip kendi üretimlerinden ekimlik tohum ayırıp geleneksel yöntemlere dönmektedir.

Tablo 7: Çiftçi Gelir Hesabı

\begin{tabular}{|l|l|l|}
\hline & Pamuk & Buğday \\
\hline Dönüm (dekar) & 45 & 20 \\
\hline Toplam ürün (kg) & 22.500 & 11.000 \\
\hline
\end{tabular}


Taşdoğan, B ve Ağdemir, Z.. (2019), "Kapitalizm, Devlet ve Köylü: Gaziantep Köylerinde Ampirik Bir Çalışma”, Politik Ekonomik Kuram, Cilt 3(2)

\begin{tabular}{|l|l|l|}
\hline Dönüm baş1 verim $(\mathrm{kg})^{*}$ & 500 & 550 \\
\hline Tüccar fiyat $(\mathrm{kg} / \mathrm{krş})$ & $1,69 \mathrm{kr} ̧ ̧$ & $0,73 \mathrm{krş}$ \\
\hline Destekleme $(\mathrm{kg} / \mathrm{krş})^{* *}$ & $0,65 \mathrm{krş}$ & $0,05 \mathrm{krş}$ \\
\hline Toplam hasılat & $51.750 \mathrm{TL}$ & $8.580 \mathrm{TL}$ \\
\hline Net Kar / dönüm baş1*** & $525,15 \mathrm{TL}$ & $178,05 \mathrm{TL}$ \\
\hline
\end{tabular}

* Dönüm başı 500 kg verim, o bölge için alınabilecek maksimum sınırdır. Çoğu çiftçi özellikle gübre ve ilaçtan kısıntıya gittiği için ortalama $300 \mathrm{~kg}$ civarında ürün elde etmektedir.

** Kaynak (www.etb.org.tr, 2016).

*** Köylü üreticinin geçinmesi için elde ettiği bu gelirden kendini yeniden üretmesi için gerekli olan sonraki senenin ekimi için girdilerini ve eğer besliyorsa hayvanı için yem, ilaç vb. masrafları yapacaktır. Yani enflasyon ve döviz kurunun sabit olduğu varsayımında üretici dönüm başı minimum 623, 84 TL masraf yapacak ve dönüm başı 148,84 TL zarar edecektir. Eğer köylü üretici topră̆ icara almışsa kâr ve zarar \%50 paylaşılacaktır. Maliyet hesaplarına köylü üretici tarlasındaki kendi çalışmasını iş̧̧ilik olarak yansıtmamıştır. Köylü kullandığg traktör, pulluk tarım makinelerinin amortismanını yansıtmamıştır. Yine köylünün sigorta, yemek vb. gibi işveren üzerindeki diğer maliyet unsurları yansıtılmamıştır. Benzer durum buğday üretimi için de geçerlidir.

Geleneksel kapitalist eklemlenme sürecinde tüccar-tefeci sermayesini önemli rol düşmektedir. Bu durum günümüzde her ne kadar finansal sermayeye geçmiş olsa da, klasik tarımsal üretim ilişkilerinin geçerliliği tüccar hesapları üzerinden de incelenmiştir. Tüccar-tefeciliğin eski ya da teorik olarak belirtilen köylülüğü sömüren karlılık ilişkilerini koruyup korumadığı ortaya konulmak istenmiştir. Buna göre yine köylünün ürettiği iki temel ürün buğday ve pamuğun tüccar elindeki değeri Tablo 8'de hesaplanmaya çalışılmıştır.

Tablo 8: Tüccar Maliyet Hesabı

\begin{tabular}{|l|l|l|}
\hline Ürün & Buğday & Pamuk \\
\hline Ortalama alım miktarı $(\mathrm{kg})$ & $2000-2500$ & $2000-2500$ \\
\hline Alış fiyatı $(\mathrm{kg} / \mathrm{krş})$ & 0,73 & 1,69 \\
\hline İşleme maliyeti $(\mathrm{kg} / \mathrm{krş})$ & - & 0,12 \\
\hline Satış fiyatı $(\mathrm{kg} / \mathrm{krş})$ & 0,75 & $4,65(0,65)^{*}$ \\
\hline Kar oranı $(\%)$ & 0,28 & $12^{* *}$ \\
\hline
\end{tabular}


Taşdoğan, B ve Ağdemir, Z.. (2019), "Kapitalizm, Devlet ve Köylü: Gaziantep Köylerinde Ampirik Bir Çalışma”, Politik Ekonomik Kuram, Cilt 3(2)

* Pamuğun işleme maliyeti sonrası tüccara maliyeti 1,81 TL olmaktadır. Fakat 1 kg. kütlü pamuktan 400 gr. elyaf, 600 gr. tohum elde edildiği için elyaf ve tohum farklı fiyatlandırılmaktadır. Elyaf satış fiyatı $4,10 \mathrm{~kg} / \mathrm{TL}$ ve tohum satı̧ fiyatı ise $0,65 \mathrm{~kg} / \mathrm{krş} \mathrm{olmaktadır.}$

** Tüccar kar oranı $=[(0.40 \mathrm{~kg} * 4,10 \mathrm{~kg} / \mathrm{krş})+(0,60 \mathrm{~kg} * 65 \mathrm{~kg} / \mathrm{krş})]=2,03$ (geliri)

$2,03 / 1,81=\% 12$ kâr şeklinde hesaplanmıştır.

Çalışma kapsamında yüz yüze görüşmesi yapılan köyün en zengin ve en eski tüccarı yıllık ortalama 2 - 2,5 ton buğday ve aynı miktarda pamuk aldığını bildirmektedir. Tüccarın alış fiyatı, pamuk için dünya ortalamasına, buğday için ise ticaret borsasına göre belirlenmektedir. Tüccar ürünler için köylüye ödediği fiyattan alış göstermektedir. Buğday için tüccar al-sat yaparak kg başı 0,02 kuruş komisyon elde etmekte, kabaca \%3 kar etmektedir. Pamuk için ise süreç farklıdır. Pamuk köylüye ödenen alış fiyatı sonrası kilogram başı \%40 elyaf ve \%60 tohum olarak ayrıştırılmaktadır. Elyaf kg başı 0,12 kuruş maliyetle işlenmekte ve iplik fabrikalarına kilosu 4,10 kuruştan satılmaktadır. Ayrıştırılan tohum ise kilosu 0,65 kuruştan köylülere girdi olarak tekrar satılmaktadır. Bu iki işlem sonrası tüccar, tablo altında gösterildiği gibi, pamuktan ortalama \%12 kar elde ettiğini belirtmektedir.

Tüccar, maliyetleri düşürmelerinin tek yolunun kayıt dışı kalmak olduğunu, fakat destek ödemesi alabilmek için fatura kesme zorunluluğunun bulunduğunu, yani istense dahi kayıt dışı çalışamadıklarını bildirmektedir. Tüccar sorunu yeterli üretimin olmamasına ve bölgede elyafı sattıkları 4 fabrika olduğu halde sadece 1 tanesinin yerel tüccarlardan alım yapmasına bağlamaktadır. Elyaf fabrikalarının ağırlıklı olarak yurtdışından gelen daha kaliteli pamukları tercih ettiğini ve rekabet edemediklerini belirtmektedir. Türkiye'deki tarım üreticilerinin pamuğu el işçiliği ile topladığı için pamuğun kalitesinin ikinci dereceye düştüğünü belirtmektedir. Üstelik elle toplandıktan sonra elyaf çuvallara istiflenirken pamuk elyafi kırılarak kalitesi ikinci kez düşmektedir. Buna rağmen, makinelerin köylünün alım gücünün çok ötesinde olması nedeniyle geleneksel yönteme devam edilmektedir.

Tüccarın pamuğun toplanması için yaptığı maliyet hesabı aşağıdaki gibidir:

-Elle toplatma maliyeti $0,40 \mathrm{tl} / \mathrm{kg}$.

-Biçerdöverle toplatma maliyeti 22-26 tl/kg

(İplik fabrikaları ise birinci kalite yurtdışı malı 4,80 TL'den, ikinci kalite yurtiçi malı ise 4,10 TL'den almaktadir). 
Taşdoğan, B ve Ağdemir, Z.. (2019), "Kapitalizm, Devlet ve Köylü: Gaziantep Köylerinde Ampirik Bir Çalışma”, Politik Ekonomik Kuram, Cilt 3(2)

Özetle, küçük üretici pamuk ve buğday üretimi Tablo 7 ve 8 'de görüldüğü gibi girdi fiyatları, destek fiyatlarının düşüklügü gibi sebeplerle zarara neden olmaktadır. Tüccarın kârı ise beklendiği üzere çiftçinin üzerindedir. Yerel tüccarın kârı ise ithal pamukların kalitesinin yerel pamuğa göre iyi olmasından kaynaklı bir biçimde düşük kalmıştır.

\section{Sonuç}

Aceroba köyü dağlık bir araziye sahiptir, bu nedenle kapitalizmin sebze, meyve ve findığın üretildiği, köylünün toprağını arazi şartları, borçluluk ve kente yakınlık nedeniyle sattığı dolayısıyla köyün önemli kısmının küçük toprağa sahip olduğu geçim için hayvancılığın yapıldığı bir yerdir. Makineleşme oldukça düşük düzeydedir. Bu köy arazilerinin bağ evleri yapılmak için satılması, yani toprağın değerli olması ve köylünün borçları için topraklarını satması, köylü topraklarını gittikçe küçültmüştür. Köy tarımsal arazi nedeniyle devlet desteği alamamakta ancak yetiştirdikleri ürünlerin yüksek fiyat avantajından yararlanmaktadırlar. Bu köydeki küçük ölçekli üretim Lenin'in küçük ancak yoğun üretim yapan çiftlik örneğine uymamaktadır. Ve Lenin'in küçük üreticiliğin mülksüzleşmesinin bir sonuç değil bir süreç olduğunu düşünürsek, Aceroba köyünde artan toprak satışının, göçün ve toprağın giderek artan değerinin Marx'ın dile getirdiği toprağın fiyatına yapılan sermaye harcamasının buradaki toprak yapısının değiştirdiğini yani gittikçe küçülttüğünü söylemek yanlış olmaz. Tarımda kapitalizmin gelişimi durağan değil değişen bir yapıya sahiptir. Ancak eğer toprak satış süreçlerini ve göçleri dikkate almayıp köy nüfusunun yüzde 80'nin 10 ve daha az hektara toprağa sahip olduğunu dikkate alırsak köylücü yaklaşımın tezlerine yakınlaşmamız mümkün olur.

Sakçagözü köyünde ise ortaya çıkan ilk sonuç hayvancılık ve tarımın birlikteliğinin köylünün refah seviyesini artırmasıdır. Bu köy ova köyü olduğundan pamuk, buğday, mısır ve patatesin üretildiği aynı zamanda hayvancılığın geliştiği bir köydür. Dikkat çekici bir sonuç birikim yapan çiftçilerin hayvancılıkla uğraşmasına rağmen toprağını satan çiftçinin yüzde \%57'sinin 50 ve daha az hektar toprağını elden çıkarmasıdır. Bunun anlamı hayvancılıkta bir polarizasyon yaşandığı olarak yorumlanabilir. Diğer yandan, 2000 öncesine göre pamuk ve mısır üretiminde girdi fiyatlarının artışı, sulama ve elektrik maliyetlerinin artışı, küçük toprak sahibinin pamuk ve buğday maliyetlerinin çeşitli hesaplamalarda görüldüğü üzere zarar etmesi, artan borçluluk Lenin'in bahsettiği mülksüzleşme sürecinin aşamaları olarak değerlendirilebilir. Tarihselci 
Taşdoğan, B ve Ağdemir, Z.. (2019), "Kapitalizm, Devlet ve Köylü: Gaziantep Köylerinde Ampirik Bir Çalışma”, Politik Ekonomik Kuram, Cilt 3(2)

yaklaşıma göre küçük üreticinin varlığı, küçük üreticinin gelecekte var olacağı anlamına gelmemektedir. Ancak Chayonavcu yaklaşım ise pamuk ve buğday üretiminde zararlarına rağmen küçük çiftçinin varlığı, aile çalışan sayılarını da dikkate aldığımızda köylünün kendi emeğini sömürmesi olarak görülebilir. Ancak süreç olarak bakıldığında ise tarihselci yaklaşımın açıklayıcılığını koruduğu söylenebilir. Devletin buradaki rolünü vergiler olarak göremesek de özellikle destek fiyatlarındaki düşüklük ve girdi fiyatlarına devlet katkısının önemli bir anlam ifade etmemesi küçük köylünün durumunu kötüleştiren hususlar olarak görülebilir. Tarihselci yaklaşım devletin küçük köylü ile ilişkisini mülksüzleştirme süreci içinde ele alırken, köylücü yaklaşımda devletin belirgin bir yer tutmadığı daha çok ailenin kültürel kodları üzerinde durulduğunu görüyoruz.

\section{Kaynakça}

Akşit B., (1967), Teknolojik Gelişimi Sosyolojik Ölçüt Alan Diyalektik Bir Yaklaşım Açısından Türkiye’de Azgelişmiş Kapitalizm ve Köylere Giriş, ODTÜ Öğrenci Birliği Yayınları, Toplum Araştırma Dizisi: 1.

Amin, S., (1997), Emperyalizm ve Eşitsiz Gelişme, İstanbul: Kaynak Yayınları

Aydın, Z., (1980), Aspects of Rural Underdevelopment in South Eastern Anatolia, Yayımlanmamış Doktora Tezi, Durkheim University

Aydın, Z., (1986), Kapitalizm, Tarım Sorunu ve Azgelişmiş Ülkeler (I)”, 11. Tez, 3:126-156

Aydın, Z., (2016), “Çağdaş Tarım Sorunu ve Yeni Köylülük”, METU Studies in Development, $1: 43-63$.

Banaji J., (2002), "Review Essay: The Metamorphoses of Agrarian Capitalizm”, Journal of Agrarian Change, 2 (1): 96-119

Bernstein H., (1977), Notes on Capital and Peasantry, Review of African Political Economy, 4: 60-73.

Bernstein H., (1986), "Capitalism and Petty Commodity Production”, Social Analysis, 20:1128.

Bernstein H., (2003), "Farewells to the Peasantry", Transformation 52:1-19

Boratav K., (2010), Emperyalizm, Sosyalizm ve Türkiye, İstanbul: Yordam Yayınları.

Boratav, K, (2004), Tarımsal Yapılar ve Kapitalizm, İstanbul: İmge Kitabevi. 
Taşdoğan, B ve Ağdemir, Z.. (2019), "Kapitalizm, Devlet ve Köylü: Gaziantep Köylerinde Ampirik Bir Çalışma”, Politik Ekonomik Kuram, Cilt 3(2)

Chayanov, A.V., (1966), The Theory of Peasant Economy. In: Thorner D., Kerblay B., Smith R.E.F ed. American Economic Association, Homewood, Illinois.

Ecevit, M. (1994), “ Tarımda Kadının Toplumsal Konumu: Bazı Kavramsal İlişkiler”, Amme Idaresi Dergisi, 27(2): 89- 107.

Engels, F., (1990), “Fransa'da ve Almanya'da Köylü Sorunu” [online], Available from: www.kurtuluscephesi.com/marks/fralkoylu.html [Accesed 20 Apr 2019].

Edirne Ticaret Borsas1, (2016), [online], Available from: http://www.etb.org.tr/tr/index.html [Accesed 13 Oct 2019].

Frank A.G., (1966), “The Development of Underdevelopment”[online]. Available from: https://www.colorado.edu/geography/class homepages/geog 3682 f08/Articles/FrankDevof Underdev.pdf [Accesed 10 Apr 2019].

Gıda Tarım ve Hayvancılık Bakanlığı, Strateji Geliştirme Başkanlığı, (2014), Tarımsal Destekler Bülteni [online], Available from: https://osmaniye.tarim.gov.tr/Belgeler/TarimsalDesteklerBulteni.pdf [Accesed 05 Oct 2019]. İslamoğlu H. vd., 2008, “Türkiye’de Tarımda dönüşüm ve Küresel Piyasalarla Bütünleşme”, TÜBİTAK Projesi, Proje Kodu: 106K137.

Karaömerlioğlu M.A., (1998), "Bir Tepeden Reform Denemesi: Çiftçiyi Topraklandırma Kanununun Hikayesi" [online], Available from: http://www.birikimdergisi.com/birikimyazi/2836/bir-tepeden-reform-denemesi-ciftciyi-topraklandirma-kanununun-

hikayesi\#.Wfwj6SMS_Zs [Accesed 20 Oct 2019].

Kautsky, K., (1988), The Agrarian Question, Volume-I, Zwan Publications.

Keyder, Ç., (2017), “Türk Tarımında Küçük Meta Üretiminin Yerleşmesi”, (http://www.ata.boun.edu.tr/htr/documents/312_6/Tarim/Keyder_Turk_Tariminda_Kucuk_M eta_Uretiminin_Yerlesmesi.pdf).

Kıray, M. (1964), “Ereğli: Ağır Sanayiden Önce Bir Sahil Kasabası”, T.C. Başbakanlık DPT, Ankara.

Köylü K., (1947), “Türkiye'de Büyük Arazi Mülkleri ve Bunların İşletme Şekilleri”, T.C. Tarım Bakanlığı, Ankara Yüksek Ziraat Enstitüsü Çalışmalar: 154, Ankara Yüksek Ziraat Enstitüsü Basımevi, Ankara. 
Taşdoğan, B ve Ağdemir, Z.. (2019), "Kapitalizm, Devlet ve Köylü: Gaziantep Köylerinde Ampirik Bir Çalışma”, Politik Ekonomik Kuram, Cilt 3(2)

Köymen, O., (1999), Cumhuriyet Döneminde Tarımsal Yapı ve Tarım Politikaları. I: 75. Yılda Köylerden Şehirlere, İstanbul: Türkiye Ekonomik ve Toplumsal Tarih Vakfi, 1-31.

Lenin, V. İ., (1996), Tarımda Kapitalizm, İstanbul: Sol Yayınları.

Lenin, V. İ. (1997) Tarım Meseleleri, İstanbul: Sol Yayınları.

Lenin,V. İ., (1975), Rusya'da Kapitalizmin Gelişimi, İstanbul: Sol Yayınları.

Marx, K., (2006), Kapital-I, İstanbul: Sol Yayınları.

Önal, N., (2017), Anadolu Tarımının 150 Yıllık Öyküsü, İstanbul: Yazılama Yayınevi.

Özuğurlu, M., (2011), Küçük Köylülüğe Sermaye Kapanı: Türkiye’deki Tarım Çalışmaları ve Köylülük Üzerine Gözlemler, Ankara: Nota Bene.

Shanin, T., (1971), "Peasantry: Delineation of a Sociological Concept and a Field of Study", European Journal of Sociology, 12: 289-300.

Shanin, T., (1973), “The Nature and Logic of the Peasant Economy: A Generalisation”, Journal of Peasant Studies, 1(1): 63-80.

Şekerbannk, (2017), [online] Available from:

http://www.sekerbank.com.tr/aileciftciligi/tarlaBuyutme.html [Accesed 20 Apr 2019].

TUIKK, (2019), “Tarımsal Yapı İşletme Araştırması, 2019”, (Gıda Tarım ve Hayvancılık Bakanlığı, Strateji Geliştirme Başkanlığı, (2014), Tarımsal Destekler Bülteni [online], Available from: https://osmaniye.tarim.gov.tr/Belgeler/TarimsalDesteklerBulteni.pdf).

Wolf, E.R., (1999), Peasant Wars of the Twentieth Century, Norman: University of Oklahama Press.

6360 sayılı “On Dört İlde Büyükşehir Belediyesi ve Yirmi Yedi İlçe Kurulması ile Bazı Kanun ve Kanun Hükmünde Kararnamelerde Değişiklik Yapılmasına Dair Kanun”, (http://www.mevzuat.gov.tr/MevzuatMetin/1.5.6360.doc)

\section{Ek:}

ANKET SORULARI

1) Muhtar Mülakat1:
a. köyün tarihçesi
b. kuruluşu,
c. toplam kaç hane var?
d. köyün toplam arazileri ile ilgili sorunu var mı?
e. ağalık düzeni var mıydı? 
Taşdoğan, B ve Ağdemir, Z.. (2019), "Kapitalizm, Devlet ve Köylü: Gaziantep Köylerinde Ampirik Bir Çalışma”, Politik Ekonomik Kuram, Cilt 3(2)
f. eskiden ne ekerlerdi ?
g. pazar ilişkisi nasıldı ?
h. makineleşme ne zaman nasıl başladı?
i. göç durumu nedir ?
j. köy dışı toprak satışı var mı?
k. işçi ücretleri ne kadar nasıl belirleniyor ?
1. alt yapı hizmetleri yapılıyor mu?
m. kooperatifleşme var $\mathrm{m} ı$ ?

2) Bölüşüm İlişkileri ${ }^{15}$ :

- Aşağıdaki gelir tiplerinden hangisini elde ediyorsunuz?
a. Ticari kar
$\mathrm{E}(\mathrm{)}$,
$\mathrm{H}($ )
b. Faiz
$\mathrm{E}(\mathrm{)}$,
$\mathrm{H}(\mathrm{)}$
c. Toprak Kirası
$\mathrm{E}(\mathrm{)}$,
$\mathrm{H}(\mathrm{)}$
d. Tarımsal Kar
$\mathrm{E}(\mathrm{)}$,
$\mathrm{H}(\mathrm{)}$
e. Tarımdan gelir
$\mathrm{E}(\mathrm{)}$,
$\mathrm{H}(\mathrm{)}$
f. Ücret
E ( ),
$\mathrm{H}(\mathrm{)}$

3) Gelir tipi ve meslek bileşeni:

- Çiftçilik dışında bir işte çalışıyor musunuz? E ( ),
a. İşiniz geçici mi?
E ( ),
$\mathrm{H}(\mathrm{)}$
b. Kalıcı mi?
$\mathrm{E}(\mathrm{)})$
$\mathrm{H}(\mathrm{)}$

4) İşlenilen toprak dışında kullanılan aletlere sahip misiniz? E ( ),

$\mathrm{H}(\mathrm{)}$

- Sahip olunan aletler nelerdir ve sayıları?
a) Traktör, (kaç beygir)
b) Diğer

5) İşlenilen toprak dışında hayvan sahibi misiniz?

E ( ), $\quad \mathrm{H}(\mathrm{C})$

6) Hayvan besleme gerekçeniz? Kendim için ( ),

Gelir için ( )

\footnotetext{
${ }^{15}$ Boratav (2004) çalışmasında bölüşüm ilişkilerini belirlemeye çalışıyor. Kategorilerini ayrıştırmaya çalışıyor. Bunların toplamı gayri safi hasılayı vermektedir. Gayri Safi hasıladan maliyetleri çıkarınca safi hasılayı ve oradan da sömürü oranını bulmaktadır.
} 
Taşdoğan, B ve Ağdemir, Z.. (2019), "Kapitalizm, Devlet ve Köylü: Gaziantep Köylerinde Ampirik Bir Çalışma”, Politik Ekonomik Kuram, Cilt 3(2)

7) Yem maliyetini nasıl karşıllyor sunuz?

Merada otluyor ( ), Para ile allyorum ( ), $\quad$ Ekiyorum ( ), Devlet destekliyor ( )

$$
\begin{array}{ll}
\text { - } & \text { İnek (adet) } \\
\text { - } & \text { Keçi (adet) }
\end{array}
$$

8) Toprak büyüklüğü ve üretim

- Hangi ürünleri üretiyor musunuz?
a. Birincil ürün
b. İkincil ürün
c. Üçüncül ürün

- Toprak kiralıyor musunuz?

$$
\mathrm{E}(\mathrm{)}, \quad \mathrm{H}(\mathrm{)}
$$

- Toprağınızı kiraya veriyor musunuz?

E ( ), H( )

- Tarımda çalışıyor musunuz?

E ( ), $\quad \mathrm{H}(\mathrm{r})$

- Ücretli işçi çalıştırıyor musunuz?

E ( ), H( )

Kaç gün?

Hangi işte? (Dikim, bakım, sulama, hasat vb.)

- Kadın ve çocuklar çalışıyor mu?

$\mathrm{E}(\mathrm{)}$,

- Kadın ve çocuklar çalışmasa üretim devam edebilir mi?

$$
\text { E ( ), } \quad \mathrm{H}(\mathrm{c})
$$

- Haneden diğer tarım işlerinde çalışan var mı?

$\begin{array}{ll}\text { E ( ), } & \text { H ( ) } \\ \text { E ( ), } & \text { H ( ) }\end{array}$

- Ücretli işçilik (tarım dışı) yapıyor musunuz?

Kisa sureli mi?

Daimi mi?

Yardım amacıyla mı (ücretsiz mi?)

9) Hanehalkı büyüklüğü
a. Hane kaç kişi?
b. Aile Reisinin (asıl üreticinin) yaşı
c. Baba mesleği
d. Öğrenim durumu 
Taşdoğan, B ve Ağdemir, Z.. (2019), "Kapitalizm, Devlet ve Köylü: Gaziantep Köylerinde Ampirik Bir Çalışma”, Politik Ekonomik Kuram, Cilt 3(2)

e. Sendika kurulsa destekler misiniz, katılır mısınız?

f. Dönüm başı verim kaç kg?

g. Dönüm başı maliyet kaç tl?

h. Birikim yapabiliyor musun? E ( ) H( )

i. Birikimle ne allyorsunuz?

j. Haneden temelli göç eden hane var mı?

10) Bağımlılık Derecesi:

- $\quad$ Tohumu/gübre/ ilaç/ mazot/ kredi kimden aldı?
a. Şirket,
b. Tüccar,
c. Kooperatif,
d. Bayii,
e. Şahıs,
f. Banka,

- $\quad$ Tohumu/ gübre/ ilaç/ mazot/ kredi geri ödeme biçimi?
a. Peşin,
b. Taksit,
c. Banka kredisi,
d. Borç,
e. Veresiye,

- $\quad$ Girdilerden tasarruf yaptı mı?

$\mathrm{E}(\mathrm{H} \quad \mathrm{H}(\mathrm{)}$

- $\quad$ Ürünü kime sattı
a. Tüccar
b. Komisyoncu,
c. Fabrika,
d. Kamu,
e. Borsa/hal,
f. Kendi

- $\quad$ Ürünü sattığınız kişi girdileri aldığınız kişi mi? $\quad$ E ( ) $\quad$ H ( )

- $\quad$ Banka kredi borcunu ödeyebiliyor mu? $\quad$ E ( ) $\quad$ H ( ) 
Taşdoğan, B ve Ağdemir, Z.. (2019), "Kapitalizm, Devlet ve Köylü: Gaziantep Köylerinde Ampirik Bir Çalışma”, Politik Ekonomik Kuram, Cilt 3(2)

- $\quad$ Yoksullaşma ve mülksüzleşme eğilimleri
a. Boş bırakılan arazi var $\mathrm{m}$ ?
$\mathrm{E}(\mathrm{)}$
$\mathrm{H}(\mathrm{)}$

b. Satılan arazi var mi?

$\mathrm{E}(\mathrm{H} \quad \mathrm{H}(\mathrm{)}$

c. Satılan araç/ ekipman var mı?

$\mathrm{E}(\mathrm{r} \quad \mathrm{H}(\mathrm{l})$

d. Ücret geliri var mi?

$\mathrm{E}(\mathrm{)}$

$\mathrm{H}(\mathrm{)}$

e. Emekli maaşı var mı?

$\mathrm{E}(\mathrm{)}$

$\mathrm{H}(\mathrm{)}$

f. Sağlık güvencesi var mı?

$\mathrm{E}(\mathrm{)}$

$\mathrm{H}(\mathrm{)}$

g. Yeşil kart var mı?

$\mathrm{E}(\mathrm{r} \quad \mathrm{H}(\mathrm{)}$

h. Tarımsal geliri var mı?

$\mathrm{E}(\mathrm{)}$

$\mathrm{H}(\mathrm{)}$

i. Destek alıyor mu?

E( )

$\mathrm{H}(\mathrm{)}$

j. Enformel yardım alıyor mu?

$\mathrm{E}(\mathrm{)}$

$\mathrm{H}(\mathrm{)}$

k. Kurumsal yardım alıyor mu?

E ( )

$\mathrm{H}(\mathrm{)}$

1. Borçsuz yıl var mı?

E ( )

$\mathrm{H}(\mathrm{)}$

- $\quad$ Yaşam standardı göstergeleri
m. Kredi kartı kullanıyor mu?
$\mathrm{E}(\mathrm{)}$
$\mathrm{H}($ )
n. Borcunu düzenli öder mi?
$\mathrm{E}(\mathrm{)}$
$\mathrm{H}(\mathrm{)}$
o. Konut mülk mü?
$\mathrm{E}(\mathrm{)}$
$\mathrm{H}(\mathrm{)}$
p. Sulamada elektrik kullanılıyor mu?
$\mathrm{E}(\mathrm{)}$
$\mathrm{H}(\mathrm{)}$
q. Evde banyo bulunuyor mu?
$\mathrm{E}(\mathrm{)}$
$\mathrm{H}(\mathrm{)}$

11) Sözleşmeli tarım yapılıyor mu?

12) Firmanın kiraladığ

\section{Giriş}

İnsan, hem kendi içinde hem de diğer insanlar ve doğa ile sürekli ve kesintisiz bir ilişkinin öznesi, nesnesi konumunda. İlişki, insanın ve tüm çevresinin çok boyutluluğu göz önüne alınacak olursa fazlasıyla katmanlı ve dolayımlı. Bu karmaşık kümenin dinamikliğini hiç yitirmeyen bütününe toplum kavramı denk düşüyor. Biz, her ne kadar kendimizi merkeze koyup dışımızdakilere iradi bir katılım sağlamayı kuramsal bir başlangıç noktası olarak kabul etsek 
Taşdoğan, B ve Ağdemir, Z.. (2019), "Kapitalizm, Devlet ve Köylü: Gaziantep Köylerinde Ampirik Bir Çalışma”, Politik Ekonomik Kuram, Cilt 3(2)

dahi aslında biz ve dışımızdakiler yani birey ve toplum, birbirlerinden hiç de kolay ayrışamayacak, birbirine geçişli olan bir bütünü oluşturuyorlar. Öyleyse bu sosyal bütünün, birey/toplum ilişkiselliğinin anlamı, önemi ve tarih boyunca çeşitli nedenlerden ötürü gözetilen devamlılığı, uyumu üzerine düşünmek, doğallığıyla insanı, toplumu, anlamaya, çözümlemeye ve en soyut haliyle kuramsallaştırmaya yol açıyor. Böylesi bir kuramsallaştırmanın, özcesi, birey/toplum bağının, dinamik bir toplumsal örgütlenişin, bir arada yaşamanın ilk nedenlerini ve böylesi bir yaşamın devamlılığının özsel ilkelerini saptamaya çalışacak olsak, sanırız Platon, bizlere ilk 1şık tutan bilge olacaktır.

\section{Bir Birliktelik Arayışı: Devlet}

Platon'un Devlet ${ }^{16}$ yapıtı, siyasi düşünce tarihinin ${ }^{17}$ bir bakıma düzen inşasına, biraradalığa dönük ilk kapsamlı çalışmasıdır. Akı1/istek bileşimi olan insanın ve gereksinimlerin bağlayıcı gücüyle var olan toplumun ne olduğu/nasıl işlediği üzerine yazılmış olan Devlet' $i$, en genel haliyle toplumsal gerçekliğin idealize edilme uğraşı olarak yorumlayabiliriz ${ }^{18}$. Bir tarafta gerçek, ötede ise ideal olan. Gerçeği ideal olana yaklaştıracak, ulaştıracak gücün tanımlanmasıyla, bir bütün olarak Devlet metni, kendine özgü bir sosyal kuramı bizlere sunuyor ${ }^{19}$. Sosyal olanın, birbirinden farklı/çelişkili konumlarda bütün içinde tanımlananın, gönüllü ya da zorla olan birlikteliğin, karşılıklılığın izi sürülmeye değer ${ }^{20}$.

Uyumlu bir birliktelik ve bundan doğan süreklilik, Platon açısından ilkesel bir öneme sahip. Ne tür bir topluluk olursa olsun, eğer eğrilik amaç edinilmişse ve insanlar birbirlerine eğrilik edecekse bu topluluk iş görebilir mi diye soruyor Platon (Platon, 1999: 41). Biraradalık söz konusuysa burada eğri tutum tam olamaz çünkü eğrilik, karşındakini gözetmemeyi gerektirir.

\footnotetext{
${ }^{16}$ Devlet metninin anlamı üzerine bkz. Schofield (2007).

${ }^{17}$ Eski Yunan'da siyasi düşüncenin temel kategorilerine genel bir bakış için bkz. Cartledge (2007).

18 Sözgelimi, Strauss'a göre Devlet metni, siyasi idealizmin en geniş ve en derin çözümlemesi biçiminde değerlendirilebilir (Strauss, 1978: 127).

${ }^{19}$ Strauss'un Cicero'dan aktardığı üzere, Devlet metni, olası en iyi yönetim biçimini ortaya koymaktan öte siyasi olanın doğasını aydınlatmayı amaçlıyor (1978: 138).

${ }^{20}$ Neredeyse çözümsüz olan birey için iyi olanla, genel için iyi olan arasındaki gerilimi hep akılda tutmak koşuluyla (1978: 88).
} 
Taşdoğan, B ve Ağdemir, Z.. (2019), "Kapitalizm, Devlet ve Köylü: Gaziantep Köylerinde Ampirik Bir Çalışma”, Politik Ekonomik Kuram, Cilt 3(2)

Ortak amaçlar doğrultusunda bu umarsızlığı engelleyen şey doğruluk $k^{21}$ tur ve topluluk adına iş görebilme yalnızca eğri olmayarak olasıdır (1999:42) ${ }^{22}$.

Burada Platon, konuyu ayrıntılandırmaya geçmeden önce yöntemsel bir tutum belirliyor ve genelden özele doğru doğruluğun içeriğini belirlemenin ${ }^{23}$ daha uygun olacağına hükmediyor. Ona göre daha büyük olan, doğruluğu daha da fazla içermektedir (1999: 56). Öyleyse toplum diyoruz $^{24}$ ve toplumun kurucu ilkesi olarak Platon, özsel bir yargıya varıyor:

“... Bence toplumu yapan, insanın tek başına, kendi kendine yetmemesi, başkalarını gereksemesidir. Yoksa toplumun kurulmasında başka bir sebep var mıdır?

... bir insan bir eksiği için, bir başkasına başvurur, başka bir eksiği için de bir başkasına. Böylece birçok eksikler birçok insanların bir araya toplanmasına yola açar... (1999: 56).”

...

... "bunlar (çalışanlar-bn), toplumun içinde emeklerinin verimini, aralarında nasıl paylaşacaklar? Asıl bunun için kurmuştuk toplumu (1999: 58).”

Bu saptamalar ve şimdi aktaracağımız belirlemeler çok yalın olmakla birlikte yüzyıllar boyunca üzerine düşünülen "nasıl bir biraradalık" sorusunun en temel özgünlüklerine göndermede bulunmaktadır. İnsan olmaya özgü gereksinimlerin zorlayıcı gücü ve birlikte yaşamanın bu gereksinimleri sağlamada doğurduğu kolaylıklar temelinde (kuşkusuz kime, neye göre, nasıl sorularının çetinliğine ilişmeksizin) önce doymalıyız diyor Platon. Daha sonra barınma ve giyecek gereksinimi giderilmeli (1996: 56). Tüm bunlar belirli bir işi gerektirdiğinden, ki kişiye özgü iş istenilen biçimde gerçekleşirse doğruluk belirecektir (1999: 111), ister istemez

\footnotetext{
${ }^{21}$ Eyuboğlu ve Cimcoz çevirisi ekseninde bir kavramın adlandırılmasındaki değişimi belirtmemiz yerinde olur. $\mathrm{Bu}$ çeviride, adalet ve adil yerine doğruluk ve doğru kavramları kullanılmaktadır. Çevirmenlere göre böylesi bir kullanım, düşüncenin akışını ve bu kavramların halk diline yakınlığını daha tam sağlıyor (1999: 7). Bu nedenle ikili kullanımdan doğabilecek kavramsal birliğin zedelenmesini göze alarak Devlet metni çevirisi özelinde çevirmenlerin tercihlerine uyarak ilerlemeyi yeğledik.

${ }^{22}$ Gorgias metni ilgiyi hak ediyor kanısındayız. “...; doğrulukla, ölçüyle davranarak mutlu olmalı, başıboş tutkularından ötürü acı çekmemeli, sonu gelmez isteklerini doyurmak için haydutça yaşamamalı. Yoksa insanın da, tanrının da dostu olmaz öylesi, çünkü kaynaşma yeteneği yoktur onda, kaynaşma yeteneği olmayınca da dostluk olmaz... (2017: 116).”

${ }^{23}$ Doğruluğu hayata geçirme zorluğu, genel için iyi olanla birey için iyi olan arasındaki gerilimle ilişkili. Bu zorluk, bunların özdeş olması halinde ortadan kalkar (1978: 91). Doğruluğun felsefi derinliğine ilişkin bir açılamayı Strauss'ta görebiliriz. Onun yorumuyla doğruluk bir örüntü. Bireyin ya da toplumun yakınsayabileceği bir form, bir idea (1978: 118).

${ }^{24}$ Kratylos metninde kışkırtıcı bir soru belirir: "Birlikte daha iyi olacağı umulan bir varlığın toplumda yaşamak isteğinden daha büyük bir istek var mıdır (2017: 217)?”
} 
Taşdoğan, B ve Ağdemir, Z.. (2019), "Kapitalizm, Devlet ve Köylü: Gaziantep Köylerinde Ampirik Bir Çalışma”, Politik Ekonomik Kuram, Cilt 3(2)

işbölümü ${ }^{25}$ doğacaktır. Yine Platon biraradalık sorunu ekseninde düşünce tarihinde sıkça ifade edilen argümanları dile getirmekte:

“... İnsanlar yaradılıştan birbirine benzemezler. Kimi şu işe, kimi bu işe daha yatkın değil midir?

$\ldots$

“...insan başka işlerle uğraşacağına, yaradılışına uygun olan işi zamanında görürse, iş gelișir, hem daha güzel, hem daha kolay olur (abç) (1999: 57).”

Sosyal kuramın gerekliliği, yani biraradalığın nasıl sorunsuz inşa edileceği, yavaş yavaş belirmekte. Gereksinimlerin artan çeşitliği, işbölümüne bağlı yetkinleşmeyle daha da incelikli hale gelen mallar, kendine yeterliliğin ötesine taşan bir toplumsal yapılanma... Platon, karmaşık örgütlenmeye doğru yönelen tarihsel evrimi ne de güzel resmetmiş:

“...Gürbüz olan önceki toplum yetmiyor. Ona yaşamak için gerekli olmayan bir sürü işler, işçiler katacağız. Şehrimiz şiştikçe şişecek. Türlü türlü avcılar, renk ve çizgilerle çalışan sürü sürü resim ustaları, çalgıcılar, şairler ve şairlerin hizmetinde okuyucular, korolar, oyuncular, oyun kurucular, çeşit çeşit eşya yapmak için sürüyle işçiler... Bu arada kendi işlerimizi gördürecek kimseler de arayacağım... (1999: 60).”

Kuşkusuz bu soruşturma tek başına kuramsal bir egzersize işaret etmiyor. Aslında, karşı karşıya kalınan, deneyimlenen bir toplumsal durumun değerlendirilmesinden hareket edilmektedir. Durağan, her şeyin yerli yerinde olduğu, gereksinimlerin en sınırda tutulduğu bir örgütlenmede doğruluk soruşturması pek tabii çok kolay olacaktır. Oysa ki, sosyal kuramın, yani nasıl bir biraradalık sorusunun açıklık kazanacağı, doğruluğun anlamının daha da karmaşık ve zahmetli hale geleceği yer, örgütlenmenin çok boyutlu bir evreye ulaştığı katmanlı toplum yapısıdır²6. Çok katmanlı yapı doğallığıyla sınıfsal ayrışmanın daha da belirgin olmasını doğuruyor. Bir masal anlatımında ifadesini bulsa da verili olan, meşrulaştırılarak ortaya konuluyor:

“...sizi yaratan Tanrı, aranızdan önder olarak yarattıklarının mayasına altın katmıştır. Onlar bunun için baş tacı olurlar. Yardımcı olarak yarattıklarının mayasına gümüş, çiftçiler ve öbür işçilerin mayasına da demir ve tunç katmıştır...(1999: 96).”

\footnotetext{
${ }^{25}$ Başkalarının ya da genelin iyiliğini gözeten, keskin çizgilerle ayrılmış, belirgin bir işbölümü. Staruss'a göre bu yaklaşım, Devlet metninin tüm öğretisine sinmiş durumdadır (1978: 79). Tam da bu belirgin işbölümünün aksaması, ortadan kalkması, hoşnutsuzlukların, toplumsal gerilimlerin doğmasına kapı aralar (1978: 96).

${ }^{26}$ Bir bakıma maddi zenginliğin derinleşmesi. Zenginliğe dönük arzunun giderilmesinde doğruluk belirleyici (1978: 104).
} 
Taşdoğan, B ve Ağdemir, Z.. (2019), "Kapitalizm, Devlet ve Köylü: Gaziantep Köylerinde Ampirik Bir Çalışma”, Politik Ekonomik Kuram, Cilt 3(2)

Yöneten, yönetilen keskin ayrımı üzerinden şekillenen sosyal kuram, son tahlilde tüm toplumun mutluluğunu ${ }^{27}$ gözetmeyi amaçliyor (1999: 99). Tüm yurttaşlara verili koşullar altında mutluluk sağlayan bir devletin inşası (bilge, yiğit, ölçülü ve doğru eksenli) asıl olandır. Bizim devlet tasarımımız diyor Platon, gerçekleşirse en iyisidir, bu ne kadar zor olsa da olanaksız değildir (1999: 173$)^{28}$.

$\mathrm{Bu}$ inşanın asli mimarı bilgiyle donanmış olan sınırlı sayıda kişidir. Bu bilgi, bilgelik ${ }^{29}$ olarak ifade edilir (1999: 107) ${ }^{30}$. Burada, sık sık vurgulayacağımız, Platon'un sosyal kuramı ve bilgi kuramı geçişliliğine vurgu yapmak yerinde olacak $^{31}$. Bilginin aşkın karakterli oluşu ve edinilmesinin güç olması ile yönetenlerin sahip olabileceği bilginin değeri birbirini bütünlüyor gibidir. Tüm sadeliği ile şu denebilir: yönetmek ayrıcalıklı, farklı bir bilgiye erişmekle olası. Yöneten kesimin sınırlı sayıda oluşu, bu bilgi kümesine herkesin varamayacağı yargısı ile temellendiriliyor. Görünenin ötesini bilmek ne kadar zahmetliyse yönetmenin bilgisi de o kadar zor elde edilmektedir. Bu kuramsal inşanın doğal bir ayrım üzerinden şekillendiği savı tüm karşı çıkışları savuşturmaya yarar görünmektedir. Doğanın, kimilerini filozof ve devlet adamı, kimilerini de -pek tabii çoğunluk- düşünmeden söyleneni yerine getirecek insanlar olarak yarattığı (1999: 149) savı, Platon'un sosyal kuramını bütünlüyor ${ }^{32}$. Peki, bu bilge kişi nasıl iş görür sorusu o halde anlamlı görünüyor:

"Devleti ve insan huylarını, üstüne resim yapılacak bir bez gibi ele alacaklar, önce bu bezi temizleyecekler; bu da kolay bir iş değildir. Bugünkü kanun koyuculara benzemeyerek, filozoflar ister bir tek insanı, ister bütün bir devleti ele aldıkları zaman, kanunları çizmeden önce, insanın da devletin de temiz olmasını isterler, temiz değilse, kendileri temizlerler.

\footnotetext{
27 Gorgias metninde şu soruyla karşılaşıyoruz: “... Mutlulukla mutsuzluğun ne olduklarını bilip bilmemek... Hangi konu bundan daha önemli olabilir? Bunları bilmemekten daha utandırıcı ne vardır (Platon: 2017: 75)?”

${ }^{28}$ Felsefenin gerçekleştirebileceği doğruluk, mutluluk uyumu (1978: 127).

${ }^{29}$ Bilgeliğin ne olduğunun kesinlenemediği ama öte yandan derinlikli bir soruşturmaya konu edildiği nefis pasajlar için bkz. Kharmides.

${ }^{30}$ Politik gücün ve felsefi bilgeliğin birleşmesinden, kaynaşmasından doğacak olan ideal devlet tasarımı. Bu çerçevede, değerli bir ayrıntılandırma için bkz. Klosko, 2006: 170-191. Bu iki eksenin uyuşumu her ne kadar çok zor olsa da olanaksız değildir (1978: 123).

${ }^{31}$ Bu vurgu için bkz., Wood, 2008: 77.

${ }^{32}$ Wood, siyaset kuramlarının gelişimi ile tarihsel durum arasında muazzam bir karşılıklı ilişki ağı kuruyor (2008).
} 
Taşdoğan, B ve Ağdemir, Z.. (2019), "Kapitalizm, Devlet ve Köylü: Gaziantep Köylerinde Ampirik Bir Çalışma”, Politik Ekonomik Kuram, Cilt 3(2)

... durmadan bir modele, bir esere bakarak modellerini tamamlamaya çalışırlar. Bir yandan doğruluğun, güzelliğin, ölçünün ve diğer değerlerin özüne, bir yandan da, bunlardan insanlar için çıkarttıkları taslağa bakarlar. İnsan renklerini, sanatlarına göre ezer, birbirine karıştırır ve Homeros'un insanlarda rastlayıp da, Tanrısal dediği örneği, hep göz önünde tutarlar.

..

Yaptıklarından kâh bir çizgi siler, kâh onlara bir çizgi ekler, uğraşır didinirler; ta ki çizdikleri insan tabiatları Tanrılara görünebileceği kadar hoş görünsün (1999: 171, 172).”

Ama hemen belirtilmeli ki böylesine katı bir ayrışma, yönetene sınırsız iş görme ya da bütünü umursamadan davranma hakkını vermiyor. Platon'un sosyal kuramında şu belirlemeler aslında hiyerarşinin, egemenliğin meşruluğunu dile getirdiği kadar, toplumsal bütünlüğün sürekliliğinin, uyumunun da göz ardı edilmemesi gerektiğini vurgular:

“... kanunların kaygısı birtakım yurttaşlara ötekilerden üstün bir mutluluk sağlamak değil, yurttaşları ya inandırarak, ya zorlayarak birleştirmek, her birine toplum içinde görebileceği iş payını aldırmak, böylece bütün toplumu birden mutluluğa götürmektir. Devlet seçkin yurttaşlar yetiştirmeye uğraşıyorsa, bu onların keyiflerince yaşayıp, dilediklerini yapmaları için değil, devlet düzenini sağlamlaştırmaya yardım etmeleri içindir (1999: 187).”

Uyuma, düzene, biraradalık inşasının aksamasına yönelik tehditler yok mu? Pek tabii ki var. Tarihsel maddi gelişimle çok daha belirgin bir güç haline gelen işsiz ve mülksüzler kitlesi Platon için büyük bir sorun oluşturur. Platon, hayret uyandıran bir uzak görüşlülükle amaçladığı, arzu ettiği toplumsal düzeninin düşmanlarını ne de ilginç tarif etmekte:

“...Mallarını ellerinden alanlara ve bütün yurttaşlara kin besler, gizli gizli toplanıp onlara kötülük etme yollarını ararlar. Bütün düşünceleri devleti yıkmak, düzeni değiştirmek olur (1999: 220).”

Oysa bütün karmaşık çelişkileri, yönetimsel ayrılıkları çözecek ve bütünün istikrarını sağlayacak genel ilke Platon açısından çok nettir:

“... biz herkes için, Tanrısal ve bilge bir varlığın buyruğu altına girmenin çok daha kârlı olduğuna inanıyoruz; bu varlık ister kendi içimizde olsun-en iyisi bu tabii-, ister dışarıdan yönetsin bizi...(1999: 255).”

\section{Bilge Yöneticinin Betimlenişi: Devlet Adamı}


Taşdoğan, B ve Ağdemir, Z.. (2019), "Kapitalizm, Devlet ve Köylü: Gaziantep Köylerinde Ampirik Bir Çalışma”, Politik Ekonomik Kuram, Cilt 3(2)

$\mathrm{Bu}$ noktada, nasıl bir bilge varlık sorusu kaçınılmaz olarak belirecektir. Platon'un Devlet $A d a m \imath^{33}$ yapıtı, bir ölçüde, Tanrısal yönetici anlayışının dünyevi hale getirilmesi biçiminde yorumlanabilir. İdeal olanın, ideal işleyişin, bir noktadan sonra gerçek olanın çeşitliliği, karmaşıklığı ve değişkenliği karşısında belirleyici/düzenleyici olmaya yetmemesi, soruşturmayı derinleştirmeye yol açıyor. Kuşkusuz, ideal olana mutlak bağlılık yok sayılmaksızın var olan toplumsal gerçekliğe yönelme ve ilkeleri var olan üzerinden şekillendirme, çözümlemeye temel alınmaktadır.

Evrendeki iyi olan her şeyin Tanrı üzerinden tanımlanması ama bir süre sonra Tanrı'nın geri çekilmesi ile yardımsız kalan insanların bocalaması, çatışmadan uzak bir sosyal düzen inşasını anlamlı kılan bir durumdur. Tanrı'dan bağımsız, kendi başına iş görme hali, insanların yaşamlarını kendi çabalarıyla düzenlemeye yol açmaktadır. Benzemeye çalıştıkları evrensel varlık gibi insanlar da diyor Platon, kendi kendilerinin egemeni olmaya başlıyorlar (2011: 60). Bu egemenliğin niteliği, yani nasıl bir egemenlik sorusu, sosyal düzenin ne, nasıl olduğuna ilişkin açık bir kanıtı bizlere sunuyor. Platon'a göre insanlar üzerinde kurulması gereken egemenliğin mimarı krallık bilgisidir ve bunun ötesinde kimse hak iddia edemez (2011: 62). Burada, Tanrısal yönetici/düzenleyici güçten bu kadar çabuk dolaysız dünyevi kral egemenliğine geçiş, kolaycı bir tutum biçiminde yorumlanabilir mi sorusu bizce anlamlı görünmektedir. Toplumsal yapılanmanın, insanlık tarihinin erken dönem evrelerinde dahi karmaşık olan doğasını kavrama güçlüğü böylesine bir benzeşmeye yol açmış olabilir. Kuşkusuz yöneten gücün az sayıda oluşu, ideal olanı bilme ve gerçeği ideale yaklaştırmada, Platon'a sosyal kuramını örerken bir kolaylık sağlıyor. Şöyle bir geçişliliği tekrar vurguluyoruz: ideal bilgi kendisini herkese açmaz ve bu nedenle az sayıda kişi yönetim bilgisine sahip olabilir. Böyleyse, sosyal düzenin çelişkili doğası çok sade/tekçi bir yönetimle giderilebilir ${ }^{34}$ : “Gerçek anlamda bir yönetim varsa bu yönetim altında bir ya da iki kişi iktidarı elinde tutmalıdır (2011: 86).” Öncesinde de belirtmiştik, Platon'un bilgi kuramı, sosyal kuramını bir bakıma kolaylaştıran bir işleve sahiptir.

Platon, gerçek olanı, yaşananı görüyor, biliyor ama sosyalin inşasında, uyumlu bir biraradalık soruşturmasında, yönetme sorununun temeline, yaşanan gerçek çelişkileri koymamayı yeğliyor. Yönetim biçimlerinin, kısacası yönetme hakkının asıl belirleyeni Platon’a göre:

\footnotetext{
${ }^{33} \mathrm{Bu}$ metnin sade bir sunumu için bkz., Rowe (2007).

${ }^{34}$ Kriton metnine işaret etmek isteriz: “..., çoğunluk bizim için ne düşünecek diye kendimizi bu kadar sıkıntıya sokmamak; doğru ve yanlış üstüne usta olan adamın, tek yargıcının diyeceğini önemsemek gerekir... (2017: 286).”
} 
Taşdoğan, B ve Ağdemir, Z.. (2019), “Kapitalizm, Devlet ve Köylü: Gaziantep Köylerinde Ampirik Bir Çalışma”, Politik Ekonomik Kuram, Cilt 3(2)

“... ilkelerimize uygun davranacaksak yönetim biçimlerini birbirlerinden ayırmaya yarayan kavramların, bir, birçok, çokluk, zor kullanma, istenilerek yapma ya da fakirlik ve zenginlik olmadığını, bunların bir bilimle ayrıldıklarını göstermeliyiz (abç)...

... İnsanları yönetme bilimi en zor bilimdir ve zorlukla elde edilir. Böyle bir bilim hangi yönetim biçiminde bulunur? Eğer bilgili kralla rakiplerini birbirinden uzaklaştırmak istiyorsak bu bilimi incelemeliyiz $(2011: 85,86)$.”

Gerçek bilime hakim olan yönetim biçimi altında yönetici azınlık, devleti, bilim ve doğruluk temelinde gözetir ve iyi kalmaya özen gösterirse böylesine bir yönetim tek doğru yönetim biçimi olacaktır (2011: 87). Bu doğru yönetim biçiminde kölelere çok az da olsa bir rol verilmesi dahi kabul edilemez. Üretici ya da ticaretle ilgilenen kesim ise olsa olsa yönetimde değil ticarete ilişkin konularda söz sahibi olabilirler (2011: 82).

Kitlelerin yönetim sürecinde bu şekilde dışta tutulması bizi yine bilgi kuramı/ sosyal kuram geçişliliğine ulaştırıyor:

“Çok sayıda insan bir topluluğu yönetmek için böyle bir politik bilgelik ve akla asla tamamen sahip olamayacaktır. Tam aksine bu tek doğru yönetimi küçük bir azınlıkta, birkaç kişide hatta yalnızca bir kişide olmasını beklemek gerekir. Diğer yönetimlere ise doğru yönetimin bazen iyi, bazense kötü taklitleri demek gerekir (2011: 92).”

Yöneten/yönetilen ayrımının bu kadar kesin ve doğal ortaya konduğu bir yapıda, bu keskin ayrımdan doğacak uyuşmazlıkları bir tarafa koyacak olursak, genelin, toplumun adına en temelde, uyum, süreklilik ve mutluluk gözetilmektedir. Dokumacı ve dokuma benzetmesi Platon'un sosyal kuramını daha açık ediyor. Her şeyi daha güzel biçimde dokuyan devletin yönetim bilgisinin sahibi kral, yönetimsel örgütlenmeyi ölçülü ve enerjik insan karakterlerini dengeleyerek sağlar ve böylece Platon bir ölçüde son sözünü söyler gibidir:

“... krallık bilimi her ikisi de insani olan enerjik ve ölçülü karakterleri bir araya getirerek her iki hayatı anlaşma dostlukla bir araya getirdiği, böylelikle kumaşların en güzelini, en harikasını oluşturduğu, her kentte köle ve efendi olsun, tüm halkın bu kumaşın içinde olduğu, herkesin mekiği dokuduğu, kente durup dinlenmeksizin hak ettiği mutluluğu verdiği ve böylece onu emir ve yönetimi altında tuttuğu zaman, devlet sanatının dokuduğu kumaşın, hiç aksamdan eridiğini söyleyebiliriz (2011: 114).”

\section{Toplumsal Yaşayışın Somut İlkelere Bağlanması: Yasalar}


Taşdoğan, B ve Ağdemir, Z.. (2019), "Kapitalizm, Devlet ve Köylü: Gaziantep Köylerinde Ampirik Bir Çalışma”, Politik Ekonomik Kuram, Cilt 3(2)

Platon'un sosyal kuramının daha da net bir görünüm kazandığı, öncesinde ortaya konan genellemelerin somutlandığg, ayrıntılandırıldığı Yasalar $^{35}$ metni, insanın özelliklerinin neliği soruşturmasından hareketle toplumun iyiliğini, güzelliğini kurgulamayı amaçlamaktadır. Yasal kurumlar en iyi amaca göre düzenlenirler ve en iyi şey, barış ve karşılıklı iyi niyettir (2012: 52, 53). İyi olan, Platon'un sisteminde iki ayrı düzlemde anlam bulur. İdeal olan, tanrısal olan, tüm saflığı ile beliren birbirleriyle ilişkili tanrısal iyiler: aklı başındalık, ölçülü bir huy, adalet ve yiğitliktir. Tanrısal iyilere bağlı ve ikincil olan insansal iyiler: sağlık, güzellik, bedensel güç ve sağduyudan yoksun olmayan zenginliktir. İyi olanlar böyle tanımlandığından ve tanrısal iyiler en temele konulduğundan yurttaşlara bu iyiler ekseninde yaptırımlar getirilmelidir (2012: 57). Yaptırımın ifadesi olan yasanın oluşumunda yasa yapıcı, yasaya konu olan insanı çözümlemelidir ${ }^{36}$. Burada insan alışkanlıklarını, davranışlarını şekillendiren haz ve acı belirlemesi, yüzyıllar boyunca insan doğasını anlama çabasında söylenegelen argümanlara kaynaklık eder nitelikte. Çözümleme çok sadedir:

“... acı ve haz doğal olarak fışkıran iki pınar gibidir: bunlardan gerektiği yerde, gerektiği zaman, gerektiği kadar alan, devlet olsun, birey olsun, her canlı varlık mutlu olur, buna karşılık bilinçsizce ve zamansız alan, mutsuz yaşar (2012: 64)."

Peki, böylesi tekil bir durumun genel olanla, yasa olanla bağı nasıl kurulabilir? En temel dürtülerimize ek olarak sanılara sahibizdir ve en önemlisi; iyi, kötü ayrımını yapan bir uslamlama yetimiz vardır. Eğer uslamlama genelin ortak kararı haline gelirse yasa oluşmuş olur (2012: 76). Burada, akılsal olanla yasa olanın biraradalığı Platon’un sosyal kuramı için ilkesel önemdedir ${ }^{37}$.

Yasanın gerekliliği, sosyal düzeninin, toplumsal yaşayışın çarpıklıkları, çelişkileri ölçüsünde zorunludur, anlamlıdır. Zenginliğin nasıl üretildiği, bölüşüldüğü temel problemine değinmese de çarpıklığın adını koyarken Platon, yüzyıllara 1şık tutmakta:

“...Zenginlik ile yoksulluğun olmadığı bir toplulukta, işte en soylu karakterler bu toplulukta yetişebilir: çünkü ne küstahlık ne de haksızlık, ne rekabet ne de kıskançlık görülüyor... (2012: 123).”

\footnotetext{
${ }^{35}$ Laks'a göre bu metin bir anlamda Platon'un siyaset felsefesinin 'politikleşmesi’ biçiminde görülebilir (2007: 268).

36 İnsanı anlama çabası olarak siyaset (Platon, 2012: 84).

${ }^{37}$ Yeniden Gorgias'a yönelelim: "Ruhun davranış düzenine, düzgünlüğüne de «yasalara uygunluk» ve «yasa» adı verilir. İnsanı yasalara uygun ve düzenli kılan bunlardır... (2017: 112).”
} 
Taşdoğan, B ve Ağdemir, Z.. (2019), "Kapitalizm, Devlet ve Köylü: Gaziantep Köylerinde Ampirik Bir Çalışma”, Politik Ekonomik Kuram, Cilt 3(2)

Düzenin oluşabilmesinde önemli görülen bu maddi yapı, gelişime bağlı olarak çelişkileri sürekli arttırmaktadır. Her şeyin başına buyruk şekilde, kendi isteğimize uygun olmasını talep edersek çelişkileri aşmak olası değildir. Bu karmaşanın düzenlenmesi, Platon'dan bekleneceği üzere, bütün insansal tutumların akla uymasını hedefleyerek olasıdır. Bunun genel biçimi ise yasa koyucu devlet adamının -ölçülü ve sağduyulu olan (2012: 141)- yasal düzenlemeleri bu ölçüte göre inşa etmesidir. Platon daha da ileri giderek, çoğu toplumsal çöküşlerin asli nedenini insansal tutumların bilinememesi biçiminde yorumlar (2012: 136) ve bu, son tahlilde aklın düzenleyici gücünün temel önemine işaret eder.

“... uyumların en güzeli ve en önemlisine en büyük bilgelik demek çok doğru olur; akla uygun yaşayan kişi, bu bilgelikten pay almıştır bundan yoksun olan ise, ocağını söndürür ve hiçbir şekilde kentin kurtarıcısı olamaz, bunları bilmediği için tam tersi olarak ortaya çıkar... (2012: 138).”

Yönetici/yöneten keskin ayrımının ele alınışında maddi/manevi ayrıcalıkların belirleyiciliği dikkat çekicidir. Manevi alanda: ana-babanın çocukları, yaşlıların gençleri yönetmesi uygun görülmektedir. Maddi temelde ise zenginlikten kaynaklı, soyluların soylu olmayanları ve efendilerin köleleri yönetmesi benimseniyor. Ama en önemlisi diyor Platon, bilgisizin boyun eğmesi, bilgenin de önderlik edip yönetmesidir (2012: 139).

Dahası, yönetme hakkının erdemle ilişkisi, Platon açısında ilkesel öneme sahiptir. Öyle ki, yönetmenin gerisindeki maddi zenginlik koşulunun, erdemli olunmadığı sürece hiçbir anlam ifade etmediğini belirterek ${ }^{38}$ hoş bir örneğe başvurur Platon. Diyor ki, nasıl bir kişi hızlı koşuyor ya da güzel diye bir makama atanmıyorsa sırf zengin diye de makam sahibi olmamalı. Bunun için erdem zorunludur ve dahası ölçülü de olunmalıdır (2012: 147).

Platon, sosyal düzenin inşasını gözetirken, sürekli vurguladığımız üzere maddi gerçekliği yani bozan, çürüten, insanları yanılsamaya uğratan alışverişi, zenginlik birikimini (2012: 158) biliyor, kavrıyor olsa da çözümü, düzenlemeyi hep ilkeler ve akıl aracılığıyla verili gerçeğe dayatmaya yöneliyor. Yaşamda kalmak, gereksinimleri karşılama uğraşı dahi nihayetinde ömür

\footnotetext{
${ }^{38}$ Sokrates'in Savunması'nda bir ilke 1şıldar: “... Bakın gene söylüyorum size, zenginlikle, parayla pulla elde edilmez erdem, ama zenginlik, genel olsun özel olsun her türlü iyilik ancak erdemden gelir... (2017: 26).” Ve yine Gorgias 'ta: “... sen gerçekten iyi, doğru bir adamsan, erdem yolunun sana hiçbir zararı olmaz,... Bir arada erdem yolunu tuttuktan sonra, istersek siyasete atılırız... Öyleyse, doğruluğu ve bütün erdemleri, sağlıkta da, ölümde de uygulamaktan başka iyi bir yol olmadığını öğreten aklın kılavuzluğuna uyalım... (2017: 135).”
} 
Taşdoğan, B ve Ağdemir, Z.. (2019), "Kapitalizm, Devlet ve Köylü: Gaziantep Köylerinde Ampirik Bir Çalışma”, Politik Ekonomik Kuram, Cilt 3(2)

boyunca erdemli olmanın karşısında geri planda kalmakta, ufalanmakta ${ }^{39}$ (2012: 161). Toplumsal gerçeklik karşısında Platon’un 1srarcı olduğu düzenleyici güç şöyle tariflenir:

“... ben ancak şu yasanın doğru olduğunu düşünüyorum: bir okçu gibi her seferinde yalnızca güzel bir şeyi hedefleyen ve ister zenginlik olsun ister bunun gibi erdemden uzak başak şeylerden biri olsun, bunların hepsini göz ardı eden yasa... (2012: 159).”

Bir taraftan toplumsal yapının işleyişini kendi iç mantığının ötesinde ele alıp, aklı düzenleyici temel yapıcı güç olarak tasarlama uğraşı, öte yandan insana özgü olan yönetimin/düzenin nasıllığının insan doğasını soruşturmayı gerektirmesi ama her kazı denemsi sonucu insanın yaşama ilişkin açmazları ile karşılaşılması, Platon'u sık sık vurguladığı şu sonuca evriltiyor:

“... hiçbir insan yapısı, kendini bilmezliğe ve adaletsizliğe sürüklenmeden insan işlerini kendi başına yönetmeye yeterli değil. İşte böyle düşündüğü için, o zamanlar kentlerimize insanları değil, daha tanrısal, daha üstün soydan gelme daimonları yönetici ve kral olarak getirmiş... (2012: 170).”

İnsanı inceleme çabasının zorluğu, dolambaçlı oluşu bir ölçüde kestirme bir çözüme yöneltiyor Platon'u:

“... Bizim için her şeyin ölçüsü dedikleri gibi ‘insan’ değil, daha çok tanrıdır. Öyleyse onunla dost olacak kişinin, olabildiğince ona benzemesi zorunludur, ve bu temellendirmeye göre içimizden ölçülü olanı, kendine benzediği için tanrı sever, ölçülü olmayan ise tanrıya benzemez, ona düşmandır ve adaletsizdir; öteki şeyler de aynı uslamlama ile böyledir... (2012: 174).”

Ama tekrardan şunun belirtilmesinde yarar var. Toplum ötesinde yer alan ve nihai düzenleyici olarak benimsenen düzenleyici güç ile toplumun kendi devinimi içinde oluşan açmazlara yönelik çözüm önerileri, birbirlerinden bütünüyle kopuk değildir. İnsan ilişkileri karmaşasından bunalan Platon, tanrısal akla yönelse dahi yaşamın kendi çelişkilerini ve bunlara yönelik çözüm önerilerini tümüyle görmezden gelmez. Belki de söz konusu olan, verili yapının karmaşası karşısında bir çıkışsızlıktır. Saf, akılsal, erdemli, ölçülü tanrısal özelliklere uymaya çalışan yönetici grubu ile pratik sorunlara yönelik çözümler bir arada ele alınıyor olsa da yönetimin bu

\footnotetext{
${ }^{39}$ Welles'in ifadesiyle antik dönem düşüncesinde iktisat, siyasetin ve etiğin sınırlaması altındadır (1948: 101).
} 
Taşdoğan, B ve Ağdemir, Z.. (2019), "Kapitalizm, Devlet ve Köylü: Gaziantep Köylerinde Ampirik Bir Çalışma”, Politik Ekonomik Kuram, Cilt 3(2)

saf kurgusu ile gerçek dünyevi problemlerin çelişkili doğasının birbirleriyle nasıl ilişkileneceği son çözümlemede belirsiz kalmaktadır.

Devletin dayanağı ve nihai çıkış yolu, hakka saygı göstermek (yani öte dünya) ve mal canlısı (yani maddi yaşam) olmamak biçiminde görülüyor (2012: 199). Kuşkusuz, vurgulandığı üzere, bir çırpıda toplumun kurtulamayacağı zenginlik/mülkiyet sorunu Platon'a uzak değildir. 'Dostların malı aslında ortaktır' ilkesi yerleştiğinde en iyi yasalar belirecek (2012: 202) olsa da hem zengin hem de erdemli olmanın biraradalığı olası değildir (2012: 206). Bu eksende, Platon açısından maddi zenginliğe araç olan paranın nasıl değerlendirildiğine bakacak olsak, paranın varlığı tümüyle yadsınmıyor olsa da değerler sıralamasında aşağıda yer alıyor:

“... paraya gösterilen özen en son ve üçüncü sırada gelmeli, ortada bedene, en başta da ruha özen göstermeli... devlet biçimi, değerler bu şekilde sıralanmışsa, doğru yasal düzene oturmuş demektir... (2012: 208).”

“... Bütün kentlerde zenginlik hakkında gerçeği söylemek, yani zenginliğin amacının beden, bedenin amacının da ruh olduğunu söylemek, en iyisi ve en güzelidir; zenginliğin doğal olarak hizmet ettiği amaçları iyi olmakla birlikte, ruhun ve bedenin erdeminden sonra üçüncü sırayı alabilir. Bu düşünce mutlu olmak isteyen insanın zengin olmayı değil, adaletle ve ölçüyle zengin olmayı amaçlaması gerektiğini öğretecektir... (2012: 364).”

Zenginliğin dolaysız göstergesi olan paranın sosyal düzen adına dolaylı bir konuma yerleştirilmesi, asıl önemin ruhsal yetkinleşmeye verilmesi Platon'da kritik bir tutumdur. Aslında şöyle bir geçişlilik saptanabilir kanısındayız: ruhsal ve akılsal olanla doğal olanın benzerliği, buna karşılık parasal ve ticari olanla yapay olanın benzerliği. Doğal olanın yapay olandan bağımsızlığı, ayrılığı, özellikle uyumlu bir sosyal düzen inşasında ne ölçüde olasıdır sorusu burada yine kendini duyurur ${ }^{40}$.

Siyaseti adalet olarak ifade eden Platon, bu adaletin herkesin doğal yapısına göre maddi/manevi pay alması ile anlam bulacağını söyler (2012: 222). Ona göre eşit olmayanlara kendi sınırları içinde eşitlik uygulamak en doğru yöntemdir. Yoksa eşit olmayanlara eşit davranmak değildir en doğru yöntem. Bu, eşitsizliktir Platon açısından (2012: 221). Doğru adaletten sapan eşitlik ve hoşgörü, mükemmel olanı bozuşmaya uğratır (2012:222).

Gerilim bizce dikkat çekicidir: Platon'un, sosyal ilişki ağını bir ölçüde ideale yöneltme çabasının yanı sıra bir ölçüde de sosyalin verili yapısını meşrulaştırma çabasının, vurgulanmaya değer olduğu kanısındayız.

\footnotetext{
${ }^{40}$ Yunan düşüncesinde doğal/uzlaşımsal (yapay) ayrımının önemi üzerine bkz., 2006: 2.
} 
Taşdoğan, B ve Ağdemir, Z.. (2019), "Kapitalizm, Devlet ve Köylü: Gaziantep Köylerinde Ampirik Bir Çalışma”, Politik Ekonomik Kuram, Cilt 3(2)

Yasanın varlığı, bir bakıma farklı bir sosyal yapının inşasında gerekli olduğu kadar, görünür, var olan sosyal birlikteliğin meşrulaştırılmasında da anlamlı kılınmaktadır. Köle ile özgür kişi ve efendi arasında bir ayrım gerektiğine göre diyor Platon ve insanın huysuz bir canlı olduğunu da düşünecek olursak, insan, bu zorunlu ayrıma pek de kolay razı olmaz (2012: 247). Bu razı oluşu olsa olsa yasa zorunlu kılabilir. Özcesi, en sadesinden en karmaşık olanına, yasa inşasının mantığını, bir bakıma bu durumun kendisiyle ilişkili görebiliriz.

Platon'un sosyal kuramını, yapılagelen tüm ayrıntılandırmaları kapsamı içine alan ve "nasıl bir biraradalık, toplumsal bütün” sorusu etrafında döne duran bin yıllık tartışmada sıkça yankılanan o en soyut fikri sunalım:

“... insanların kendileri için yasa koymaları ve bu yasaya göre yaşamaları zorunludur, yoksa en vahşi hayvanlardan hiçbir farklılıkları kalmaz. Bunun da nedeni şudur: hiçbir insan bir devlet içinde yaşamak için insanlara yararlı olan șeyi anlamaya, anlasa bile her zaman en iyisini yapabilmeye ve bunu istemeye yaradılıștan yeterli değildir. Her şeyden önce gerçek anlamda devlet yönetme sanatının bireysel olanla değil, toplumsal olanla ilgilenmesi gerektiğini- çünkü devleti toplum çıkarları bir arada tutar, bireysel çıkar ise dağıtır- ve toplum çıkarları bireysel çıkardan daha iyi kollanırsa, her ikisinin de toplumun da bireyin de bundan yarar sağlayacağını anlamak zordur... (abç) (2012: 370).”

“... devletin tümü ve aileniz için en iyi olanı, yalnızca bunu gözeterek ve bireyin çıkarını ikinci sıraya koyarak, ki doğrusu da bu, öyle yasa koyacă̆ım. Böylece siz bize iyi niyetle boyun eğip insan doğasına göre gideceğiniz yere gidin, biz de elimizden geldiğince en büyük özeni göstererek sizin öteki işlerinizle en ince ayrıntılarına kadar ilgileneceğiz(abç)... (2012: 434)."

Ve karşımızda genelin en geneli, Platon'un sosyal kuramının çekirdeği yer alıyor. Tanrı, toplum, birey ilişkisinde Platon'un yöntemi çok berrak:

“... En küçük etken ve edilgen duruma bakmak ve en son hedefi en ince ayrıntısına kadar gerçekleştirmek üzere, bunların her birinin başına bir yönetici koymuştur; bunlardan biri de sensin, sefil, küçücük de olsa her zaman bütüne bakan ve yönelen parçalardan birisin; oysa sen her türlü oluşumun bu sayede ortaya çıktığını, evrenin yaşamında mutlu bir özün olması için oluştuğunu, onun senin için değil senin onun için var olduğunu anlamıyorsun. Nitekim her hekim, her usta el sanatçısı her şeyi bütünü göz önüne alarak yapar, en üstün amaca yönelen parçayı bütün için gerçekleştirir, bütünü parça için değil... (abç) (2012: 410).”

\section{Sonuç Yerine}

Onun senin için değil senin onun için var olduğunu anlamak! Bu düzen kurgusunda yoksa parça bütüne kurban mı ediliyor? Yönetim bilgisinin zor elde edilebilirliği, bu bilginin saf hali olan 
Taşdoğan, B ve Ağdemir, Z.. (2019), "Kapitalizm, Devlet ve Köylü: Gaziantep Köylerinde Ampirik Bir Çalışma”, Politik Ekonomik Kuram, Cilt 3(2)

yasanın bir ölçüde kutsal, aşkın karakteri, tam da insan için inşa edilen düzeni katılaştırmakta ${ }^{41}$ ve bu, toplumun biricik öğesi olan insanı baskılamakta, araçsallaştırmaktadır ${ }^{42}$. Düzen inşasında sürekli karşımıza çıkacak olan bireysel, genel/toplumsal çıkar ayrılığının keskin ve bir ölçüde tek taraflı bir çözümlenişiyle karşı karşıyayız ${ }^{43}$. Özce, genel çıkarın yasa üzerinden anlamlandırılması ve parçanın bütüne zor yoluyla bağımlı kılınışı ekseninde ideal birliğe varışın, Platon'un yürüttüğü nasıl bir biraradalık soruşturmasında, en genel çözüme işaret ettiğini saptamak yerinde olacaktır.

Sosyal kuramı, toplumsal biraradalığın temel ilkelerini, toplumu bir arada tutan nedenleri ortaya koyma uğraşı biçiminde ele aldığımızda, Platon, özellikle toplumsal gereksinimlerin çeşitlenmesini, buna bağlı işbölümünün derinleşmesini ve bireyin başkasının yardımı olmaksızın var olamayacağını belirlediği ölçüde toplumsal yaşayışın gerçek göstergelerine işaret etmektedir. Ama ne zaman ki, toplumsal yaşayışın zenginlik/yoksulluk eksenli gerilimi kendini duyurur ve bu nedenle toplumun düzenliliği, devamlılığ daha yakıcı hale gelir, Platon'un gerçekçiliği bir ölçüde kırılır ve toplumsal karmaşanın üzeri, yasa koyucu, bilge bir kimsenin gücüyle örtülmeye çalışılır. Aslında gerçek olan, ideal olan ya da daha sade ifadeyle olan/olması gereken ikiliği geçmişten günümüze, en genel anlamda, tüm sosyal kuram denemeleri için en temel açmaza göndermede bulunuyor. Gelecek zamanlar açısından bu açmazın kapandığı yer, belki de sosyal kuramın anlamını yitirdiği yer olacak ama incelediğimiz ilk ve kapsamlı sosyal kuramın bu açmazla bizi baş başa bıraktığı açık olsa gerek.

\section{Kaynakça}

Cartledge, Paul, 2007. Greek political thought: the historical context. İçinde: C. Rowe and M. Schofield, ed. The Cambridge History of Greek and Roman Political Thought. Cambridge: Cambridge University Press.

\footnotetext{
${ }^{41}$ Yasanın değişmezliği, katılığı ölçüsünde Platon'un devlet anlayışının tarih dışılı̆̆ı üzerine bkz., 2006: 225.

${ }^{42}$ Kriton metnindeki şu çarpıcı pasajı alıntılamak yerinde olacaktır: “... Yurdun bir anadan, bir babadan ve bütün atalardan daha değerli, daha saygı değer, daha kutsal olduğunu, tanrılar ve akıllı insanlarca böyle görüldüğünü; yurt öfkeli olduğu zaman ona bir babaya gösterildiğinden daha çok sayg1 ve itaat göstermek gerektiğini; ... bütün bunları doğruluk böyle istediği için yapmak, görevinden ayrılmamak, kaçmamak, savaştan, mahkemeye kadar her yerde devlet ve yurdun buyurduğunu yapmak ya da bu buyruğu yasaların izin verdiği yollarla değiştirmek gerektiğini bilmiyorsan, nerede kalır bilgeliğin (2017: 290)?"

${ }^{43}$ Yeniden Sokrates'in Savunmast: “..., hepinize iyilik etmemi sağlayacak bir yolu seçtim, herkesin kendini düşünmekten, kendi çıkarlarının ardında koşmaktan önce erdemi, bilgeliği araması gerektiğini, devletin sırtından yararlanmaya bakmazdan önce devlete bakması gerektiğini sizlere benimsetmeye çalıştım... (2017: 33).”
} 
Taşdoğan, B ve Ağdemir, Z.. (2019), "Kapitalizm, Devlet ve Köylü: Gaziantep Köylerinde Ampirik Bir Çalışma”, Politik Ekonomik Kuram, Cilt 3(2)

Klosko, George, 2006. The Development of Plato's Political Theory. New York: Oxford University Press.

Laks, André, 2007. The Laws. İçinde: C. Rowe and M. Schofield, ed. Cambridge History of Greek and Roman Political Thought. Cambridge: Cambridge University Press.

Platon, 1999. Devlet. Çev.: Sabahattin Eyuboğlu ve M. Ali Cimcoz. İstanbul: İş Bankası Kültür Yayınları.

2011. Devlet Adamı. Çev.: Furkan Akderin. İstanbul: Say Yayınları.

2012. Yasalar. Çev.: Candan Şentuna ve Saffet Babür. İstanbul: Kabalcı Yayıncılık.

2017. Gorgias. İçinde: Diyaloglar. Çev.: M. C. Anday. İstanbul: Remzi Kitabevi.

Kratylos. İçinde: Diyaloglar. Çev.: T. Aktürel. İstanbul: Remzi Kitabevi.

Kharmides. İçinde: Diyaloglar. Çev.: T. Gökçöl. İstanbul: Remzi Kitabevi.

Kriton. İçinde: Diyaloglar. Çev.: T. Gökçöl. İstanbul: Remzi Kitabevi.

Sokrates'in Savunması. İçinde: Diyaloglar. Çev.: T. Aktürel. İstanbul: Remzi

Kitabevi.

Rowe, Christopher, 2007. The Politicus and other dialogues. İçinde: C. Rowe and M. Schofield, ed. The Cambridge History of Greek and Roman Political Thought. Cambridge: Cambridge University Press.

Schofield, Malcolm, 2007. Approaching the Republic. İçinde: C. Rowe and M. Schofield, ed. The Cambridge History of Greek and Roman Political Thought. Cambridge: Cambridge University Press.

Strauss, Leo, 1978. The City and Man. Cambridge: Cambridge University Press.

Welles, C. Bradford, 1948. The Economic Background of Plato's Communism. The Journal of Economic History 8 (Ocak): 101-114.

Wood, Ellen Meiksins, 2008. Yurttaşlardan Lordlara. Çev.: Oya Köymen. İstanbul: Yordam Kitap. 